\title{
SOSIALISASI DAN PELATIHAN PEMBUATAN HAND SANITIZER SECARA ALAMI DARI DAUN SIRIH \& JERUK NIPIS BAGI MASYARAKAT SEI. AWANG RT. 27 KELURAHAN SURGI MUFTI BANJARMASIN
}

\author{
Rezky Nefianthi ${ }^{1}$, Rabiatul Adawiyah ${ }^{2}$, Nana Citrawati Lestari ${ }^{3}$, \\ Isna Kasmilawati ${ }^{4}$, Lagiono, Maryam Agustina ${ }^{4}$ \\ $1,2,3,4,5$ STKIP PGRI Banjarmasin
}

\begin{abstract}
ABSTRAK
Penggunaan hand sanitizer menjadi alternatif yang paling mudah untuk dilakukan selama berada di luar rumah untuk menghindari paparan virus covid-19. Hand sanitizer yang efektif membunuh kuman penyakit setidaknya harus mengandung $60 \%$ alkohol. Bagi orang yang memiliki kulit sensitif terhadap alkohol, penggunaan hand sanitizer tersebut dapat menyebabkan iritasi pada kulit. Penggunaan hand sanitizer juga memunculkan keraguan pada beberapa orang karena kandungan berupa alkohol sehingga apakah tetap sah shalat meski telah menggunakannya.

Berdasarkan beberapa permasalahan di atas, muncul ide untuk membuat hand sanitizer secara alami dan tidak mengandung alkohol. Penggunaan hand sanitizer alternatif ini diharapkan dapat mengurangi kekhawatiran masyarakat terdahap penggunaan hand sanitizer. Karena hand sanitizer alternatif ini berbahan herbal dan non alkohol sehingga aman untuk kulit, ramah di kantong, dan terjamin halal digunakan. Bahan yang digunakan pada hand sanitizer alternatif ini berupa daun sirih dan jeruk nipis.

Diharapkan dengan adanya pelatihan pembuatan hand sanitizer secara alami ini dapat menjadi salah satu ide usaha bagi para ibu di lokasi pengabdian tersebut mengingat cukup tingginya kebutuhan akan penggunaan hand sanitizer pada masa pandemi saat ini. Berdasarkan permasalahan dan pemikiran yang telah dikemukan di atas, tim bermaksud untuk melakukan kegiatan pengabdian kepada masyarakat berupa «Sosialisasi dan Pelatihan Pembuatan Hand Sanitizer Secara Alami dari Daun Sirih dan Jeruk Nipis Bagi Masyarakat Sei. Awang RT. 27 Para ibu rumah tangga dan remaja puteri ini diberikan pengetahuan mengenai pembuatan hand sanitizer sebagai perlengkapan protokol kesehatan di masa pandemi Covid- 19 dari bahan alami yang aman. Kegiatan secara daring dilaksanakan untuk memberikan pelatihan mengenai mekanisme pembuatan hand sanitizer alami serta potensi pengembangan wirausaha dari hand sanitizer alami tersebut.
\end{abstract}

Kata kunci: Covid-19, Daun Sirih, Hand Sanitizer, Pelatihan, Sosialisasi

\section{SOCIALIZATION AND TRAINING FOR MAKING HAND SANITIZER NATURALLY FROM BETEL LEAVES \& LIME FOR THE COMMUNITY SEI. AWANG RT. 27 SURGI MUFTI BANJARMASIN}

\begin{abstract}
The use of hand sanitizer is the easiest alternative to do while outside the house to avoid exposure to the COVID-19 virus. An effective hand sanitizer that kills germs must contain at least $60 \%$ alcohol. For people who have sensitive skin to alcohol, the use of hand sanitizers can cause skin irritation. The use of hand sanitizers also raises doubts in some people because the content is in the form of alcohol so whether it is still valid to pray even though they have used it.

Based on some of the problems above, the idea emerged to make hand sanitizers naturally and without alcohol. The use of alternative hand sanitizers is expected to reduce public concerns about the use of hand sanitizers. Because this alternative hand sanitizer is made from herbs and non-alcoholic so it is safe for the skin, friendly on the pocket, and guaranteed to be halal to use. The ingredients used in this alternative hand sanitizer are betel leaf and lime.

It is hoped that the training in making hand sanitizers naturally can be one of the business ideas for mothers at the service location given the high demand for the use of hand sanitizers during the current pandemic. Based on the problems and thoughts that have been raised above, the team intends to carry out community service activities in the form of «Socialization and Training on Making Hand Sanitizer Naturally from Betel Leaves and Lime for the Sei Community. Awang RT. 27 These housewives and young women were given knowledge about making hand sanitizers as equipment for health protocols during the Covid-19 pandemic from safe natural
\end{abstract}


ingredients. The online activity was carried out to provide training on the mechanism for making natural hand sanitizers and the potential for entrepreneurial development of these natural hand sanitizers.

Keywords: Covid-19, Betel Leaf, Hand Sanitizer, Training, Socialization

\section{PENDAHULUAN}

\section{Analisis Situasi}

Mitra kegiatan PKM ini ialah masyarakat Gang Sei. Awang RT. 27 Kelurahan Surgi Mufti, khususnya para ibu-ibu rumah tangga dan remaja puteri. Berdasarkan survey ke lokasi pengabdian, para ibu rumah tangga di Sei. Awang RT. 27 ini bisa dikategorikan sebagai mitra yang tidak produktif secara ekonomi dan finansial. Kondisi sosial ekonomi masyarakatnya masih tergolong rendah, Dalam kehidupan sehari-hari masih banyak yang berinteraksi di luar rumah tanpa menjaga jarak dan mematuhi protokol kesehatan. Sehingga perlu disosialisasikan tentang pandemi Covid 19 \& pencegahannya serta alternatif wirausaha yang bisa dilakukan para ibu dan remaja puteri tersebut meski berada di rumah saja. Diharapkan dengan adanya pelatihan pembuatan hand sanitizer secara alami ini dapat menjadi salah satu ide usaha bagi para ibu di lokasi pengabdian tersebut mengingat cukup tingginya kebutuhan akan penggunaan hand sanitizer pada masa pandemi saat ini.

Informasi mengenai lokasi mitra cukup sulit ditemukan di internet, padahal lokasi ini masih berasa di wilayah kota Banjarmasin. Sangat sedikit informasi yang bisa didapat mengenai lokasi mitra. Berdasarkan informasi yang didapat, sungai tersebut dinamakan Sungai Awang karena sungainya yang panjang, jauh dari pemukiman dan dalam serta lebar. Sungai Awang bisa juga disebut dengan Sei. Awang memiliki panjang 1,999 meter dengan lebar 17-62 meter. Gambaran lokasiSei. Awang disajikan pada Gambar 1.1. di bawah ini.

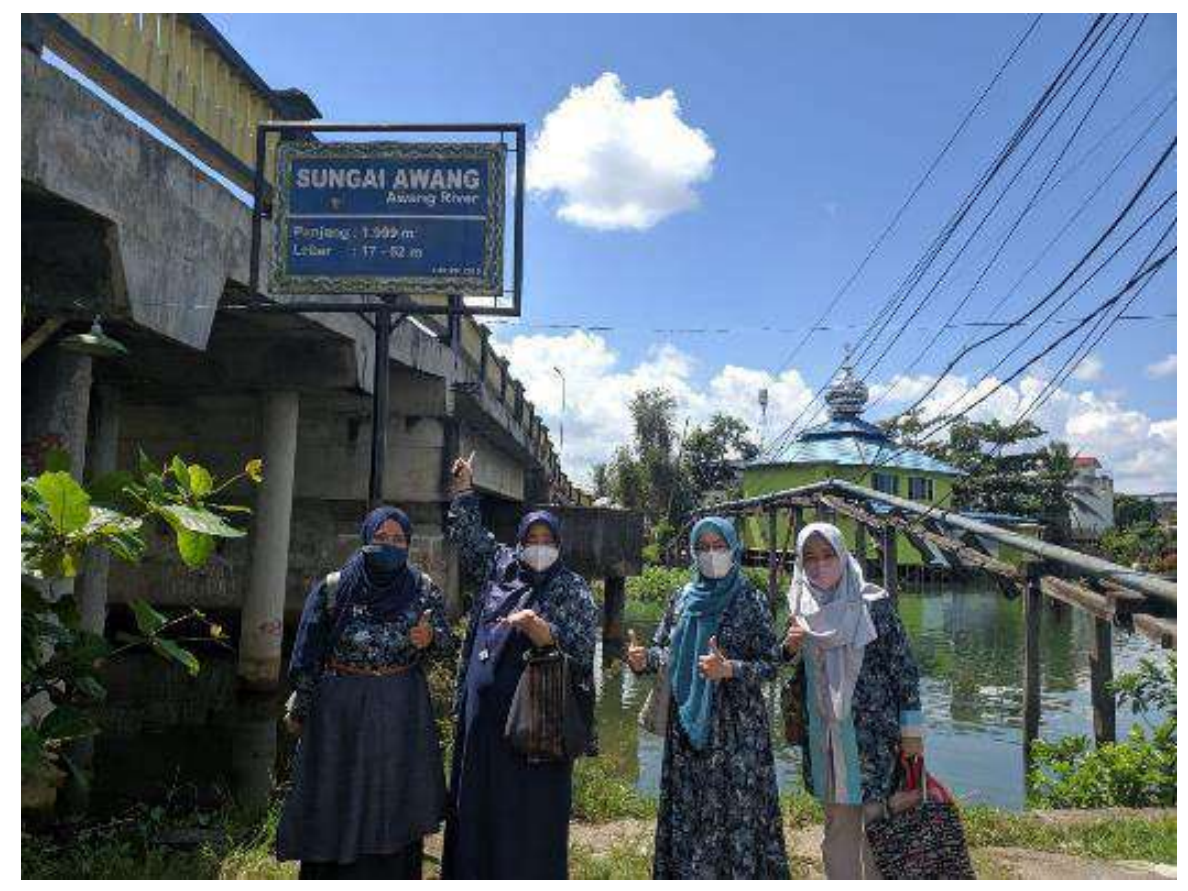

Gambar 1.1 Sei. Awang

Lokasi mitra kegiatan PKM berada di Jl. Sultan Adam Gang Sei. Awang RT. 27 Kelurahan Surgi Mufti Banjarmasin Utara. Kelurahan Sungai Andai yang terdiri dari 64 RT (Rukun Tetangga) dan 4 RW (Rukun Warga) mempunyai luas wilayah $664 \mathrm{Ha} \mathrm{(+/-} \mathrm{3,69} \mathrm{km2).}$ Kelurahan Sungai Andai merupakan 1 dari 10 Kelurahan yang berada di wilayah Kecamatan 
Banjarmasin Utara Kota Banjarmasin, berbatasan dengan:

1) Sebelah Utara dengan Kabupaten Barito Kuala

2) Sebelah Selatan dengan Sungai Awang

3) Sebelah Barat dengan Sungai Alalak.

4) Sebelah Timur dengan Kelurahan Sungai Jingah.

Berikut adalah gambaran peta lokasi secara umum yang disajikan pada Gambar 1.2.

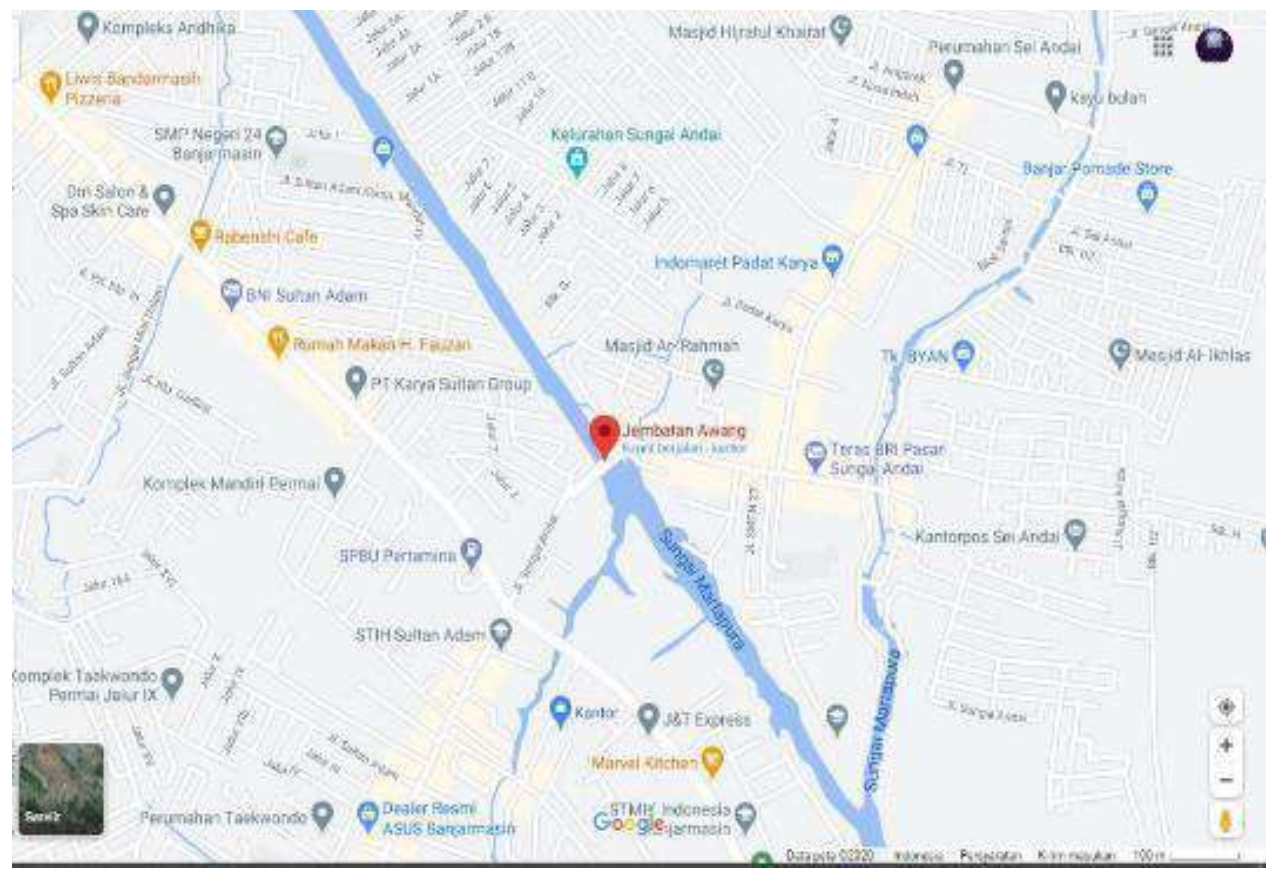

Gambar 1.2. Peta Lokasi Mitra PKM

Mitra PKM adalah warga Gang Sei. Awang yang terdiri dari ibu rumah tangga dan remaja putri. Jarak tempuh lokasi mitra sasaran dengan STKIP PGRI Banjarmasin memang tidak terlalu jauh. Namun daerah lokasi mitra kurang dikenal oleh warga Banjarmasin. Meski terletak di daerah perkotaan, namun cukup sulit menemukan lokasi mitra pada maps. Lokasi mitra berada tepat di samping jembatan Sungai Awang perbatasan antara Kelurahan Surgi Mufti \& Kelurahan Sungai Andai. Terlihat rumah-rumah warga bersusun berderat di sepanjang sungai. Ada sekitar 20-30 kepala keluarga yang tinggal di sana dengan kondisi sosial ekonomi menengah ke bawah. Sehingga perlu dilakukan observasi dan kegiatan sosialisasi serta pelatihan agar lokasi mitra nantinya bisa lebih dikenal oleh warga Banjarmasin melalui luaran yang nantinya akan dihasilkan dari kegiatan PKM ini. Lokasi Gang Sei. Awang terletak di pinggiran Sei. Awang di bawah jembatan Sungai Andai yangfotonya ditampilkan pada Gambar 1.3.

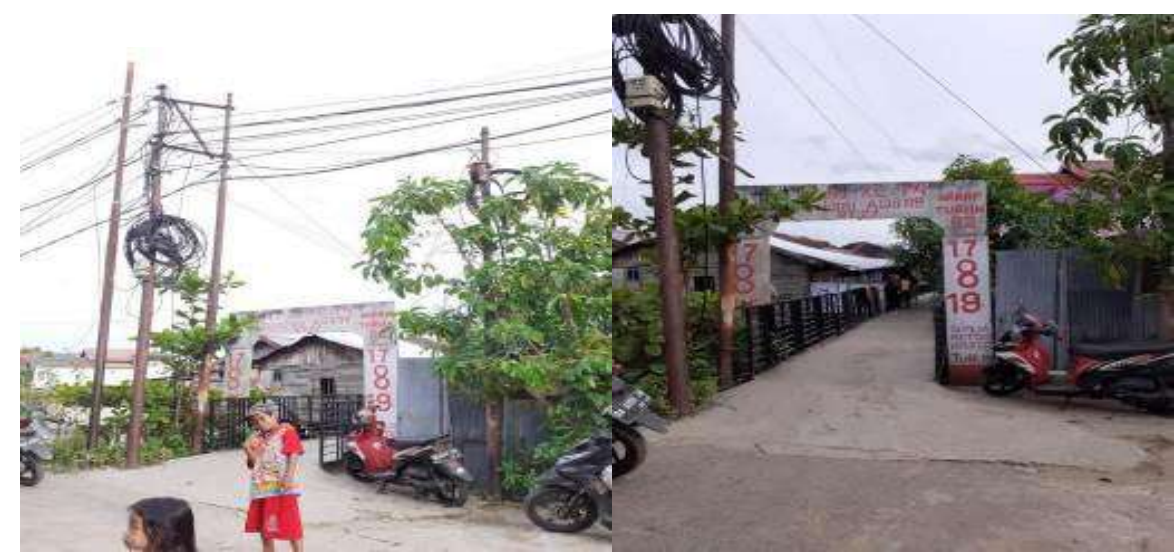

Gambar 1.3. Gang Sei. Awang sebagai Lokasi Kegiatan 
BAKTI BANUA : Jurnal Pengabdian Kepada Masyarakat

Volume 2 No. 22021

e-ISSN : 2722-3736

p-ISSN : 2722-7529

https://ejurnal.stimi-bjm.ac.id/index.php/BBJM/

\section{Permasalahan Mitra}

Pandemi corona virus adalah pandemi virus yang sedang berlangsung dari penyakit koronavirus 2019 (COVID-19), penyakit menular yang disebabkan oleh koronavirus sindrom pernapasan akut berat 2 (SARS-CoV-2). Kasus positif COVID-19 menyebar di Indonesia pertama kali pada 2 Maret 2020, ketika seorang instruktur dansa dan ibunya terkonfirmasi tertular dari seorang warga negara Jepang. Pada tanggal 9 April, pandemi sudah menyebar ke34 provinsi dengan Jakarta, Jawa Timur, dan Jawa Barat sebagai provinsi paling terpapar (Wikipedia, 2020).

Pandemi COVID-19 tidak hanya terjadi di kota-kota di Pulau Jawa. Hal ini juga dirasakan oleh masyarakat yang ada di Kalimantan Selatan, khususnya di Kota Banjarmasin. Sampai tanggal 30 November 2020, di Kalimantan Selatan terdapat sebanyak 13.170 kasus positif dengan total kematian sebanyak 520 orang. Sedangkan untuk wilayah kota Banjarmasin, terdapat sebanyak 3.641 kasus positif, dengan total kematian sebanyak 173 orang (Dinkesprovkalsel, 2020).

Kondisi banyaknya kasus positif covid-19 di Banjarmasin ini semakin meresahkan masyarakat setempat sehingga menghambat kegiatan di luar rumah. Masyarakat resah berinteraksi di luar rumah, terlebih lagi jika setelah memegang uang, bersentuhan dengan manusia lain, atau bahkan fasilitas di tempat umum. Masyarakat takut jika di tangan mereka terdapat virus COVID-19 sementara tidak semua tempat umum terdapat fasilitas mencuci tangan. Oleh karena itu lah, penggunaan hand sanitizer menjadi alternatif yang paling mudah untuk dilakukan selama berada di luar rumah.

Harga hand sanitizer sempat melambung tinggi akibat banyaknya permintaan pembeli di Indonesia (Hendarto, 2020). Meski saat ini harganya sudah menurun dan kembali normal, tetap saja kurang hemat jika digunakan untuk jangka panjang. Oleh karena itu, ada sebagian masyarakat yang membuat hand sanitizer sendiri dengan membeli bahan dasar di toko bahan kimia agar bisa lebih berhemat(Veronica, 2020).

Hand sanitizer yang efektif membunah kuman penyakit setidaknya harus mengandung $60 \%$ alkohol (Veronica, 2020). Bagi orang yang memiliki kulit sensitif terhadap alkohol, penggunaan hand sanitizer tersebut dapat menyebabkan iritasi pada kulit. Iritasi kulit ini dapat menimbulkan resiko ringan hingga berat. Seperti yang dilancir dari laman farmaku.com, ada seorang pria yang dilarikan ke UGD karena menunjukkan gejala alergi terhadap produk hand sanitzer dengan kandungan alkohol (Anonim, 2020).

Penggunaan hand sanitizer juga memunculkan keraguan pada beberapa orang. Karena kandungan berupa alkohol tersebut menyebabkan beberapa orang berpikiran dan bertanya "apakah boleh sholat menggunakan hand sanitizer?". Ada kekhawatiran jika menggunakan cairan tersebut, terutama ketika hendak sholat maka akan menyebabkan sholat menjadi tidak sah (Saputra, 2020).

Berdasarkan beberapa permasalahan di atas, muncul ide untuk membuat hand sanitizer secara alami dan tidak mengandung alkohol. Penggunaan hand sanitizer alternatif ini diharapkan dapat mengurangi kekhawatiran masyarakat terdahap penggunaan hand sanitizer. Karena hand sanitizer alternatif ini berbahan herbal dan non alkohol sehingga aman untuk kulit, ramah di kantong, dan terjaminhalal digunakan.

Bahan yang digunakan pada hand sanitizer alternatif ini berupa daun sirih dan jeruk nipis. Piper betle Linn atau tumbuhan sirih merupakan salah satu tanaman yang diketahui berkhasiat sebagai antiseptik (Sari \& Isadiartuti, 2006). Sementara itu, jeruk nipis diketahui mengandung senyawa antibakteri seperti minyak atsiri, flavonoid dan saponin (Adindaputri dkk., 2013). Kandungan pada jeruk nipis ini dapat dijadikan alternatif antibiotik. Senyawa flavonoid bersifat antioksidan, antidiabetik, antikanker, antiseptic, dan antibakteri. Selain flavonoid, senyawa fenol pada jeruk nipis mempunyai kegunaan sebagai antiseptik, desinfektan dan bahan pengawet (Ruanti, 2018). Oleh karena itu penggunaan bahan dasar daun sirih dan jeruk nipis ini dirasa tepat dalam pembuatan hand sanitizer secara alami.

Mitra kegiatan PKM ini ialah masyarakat Gang Sei. Awang RT. 27 Kelurahan Surgi Mufti, khususnya para ibu-ibu rumah tangga dan remaja puteri. Berdasarkan survey ke lokasi 
pengabdian, para ibu rumah tangga di Sei. Awang RT. 27 ini bisa dikategorikan sebagai mitra yang tidak produktif secara ekonomi dan finansial. Kondisi sosial ekonomi masyarakatnya masih tergolong rendah. Diharapkan dengan adanya pelatihan pembuatan hand sanitizer secara alami ini dapat menjadi salah satu ide usaha bagi para ibu di lokasi pengabdian tersebut mengingat cukup tingginya kebutuhan akan penggunaan hand sanitizer pada masa pandemi saat ini. Sehingga perlu disosialisasikan tentang pandemi Covid 19 \& pencegahannya serta alternatif wirausaha yang bisa dilakukan para ibu dan remaja puteri tersebut meski berada di rumah saja.

Dalam kehidupan sehari-hari masih banyak yang berinteraksi di luar rumah tanpa menjaga jarak dan mematuhi protokol kesehatan. Mereka juga ke luar rumah tanpa memakai masker seperti yang terlihat pada Gambar 1.4. Bahkan ada yang tidak tahu cara memakai masker yang benar. Kebiasaan seperti ini sangat berbahaya karena dapat membuat resiko terpaparnya virus covid-19 menjadi lebih tinggi. Oleh karena itu selain sosialisasi cara pembuatan hand sanitizer alami, maka juga dilakukan sosialisasi informasi tentang covid-19 dan protokol kesehatan.

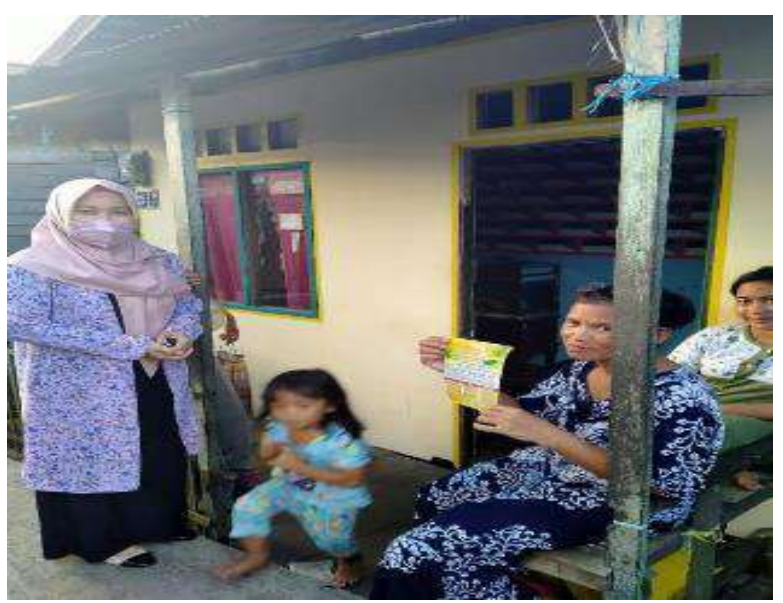

Gambar 1.4. Warga Berinteraksi di Luar Rumah Tanpa Menggunakan Masker

Berdasarkan permasalahan dan pemikiran yang telah dikemukan di atas, tim bermaksud untuk melakukan kegiatan pengabdian kepada masyarakat berupa "Sosialisasi dan Pelatihan Pembuatan Hand Sanitizer Secara Alami dari Daun Sirih dan Jeruk Nipis Bagi Masyarakat Sei. Awang RT. 27 Kelurahan Surgi Mufti Banjarmasin".

\section{Analisis SWOT}

Dalam pelaksanaan kegiatan pengabdian kepada masyarakat (PKM) ini dibuatlah analisis SWOT sebagai berikut.

A. Kekuatan

1. Lokasi kegiatan masih di wilayah perkotaan di Banjarmasin sehingga mudah dijangkau.

2. Usia warga di lokasi kegiatan masih banyak yang berada pada usiaproduktif.

3. Transportasi di sekitar lokasi penelitian tergolong mudah didapatkan dan mudah dijangkau karena bisa melalui darat dan juga perairan.

B. Kelemahan

1. Warga di lokasi kegiatan masih banyak yang belum menerapkan protokol kesehatan, seperti memakai masker, menjaga jarak, serta mencuci tangan menggunakan sabun ataupun hand sanitizer.

2. Meski sebagian besar warganya berada di usia produktif, namun banyak yang berprofesi sebagai ibu rumah tangga atau pedagang kecil saja (membuka warung di depan rumah) sehingga dapat dikategorikan sebagai mitra yang kurang produktif secara ekonomi dan finansial. 
C. Solusi Permasalahan

Solusi yang ditawarkan kepada mitra (masyarakat Sei Awang RT.27) untuk mengatasi permalasahan yang telah disampaikan pada bagian pendahuluan antara lain:

1. Melakukan sosialisasi tentang pandemi COVID-19 yang sedang terjadisaat ini.

2. Melakukan sosialisasi bagaimana cara mencegah penularan virus COVID-19.

3. Melakukan sosialisasi pembuatan hand sanitizer secara alami berbahandasar daun sirih dan jeruk nipis.

4. Melakukan pelatihan pembuatan hand sanitizer secara alami berbahandasar daun sirih dan jeruk nipis.

D. Tujuan Kegiatan

Tujuan dari kegiatan Pengabdian kepada Masyarakat ini adalah:

1. Masyarakat RT.27 Gg. Sei.Awang Kelurahan Surgi Mufti Banjarmasin memiliki pemaknaan yang positif bahwa protokol kesehatan sesuai instruksi WHO dapat dilakukan secara konsisten dengan memanfaatkan sumber daya alam alternatif, sehingga mereka tetap terjaga dari kemungkinan paparan virus Covid-19 yang masih berlangsung sampai saat ini.

2. Masyarakat RT.27 Gg. Sei.Awang Kelurahan Surgi Mufti Banjarmasin dapat mempraktikkan memproduksi hand sanitizer alami yang terbuat dari daun sirih dan jeruk nipis.

3. Masyarakat RT.27 Gg. Sei.Awang Kelurahan Surgi Mufti Banjarmasin dapat menemukan potensi wirausaha yang dapat dimanfaatkan dari hand sanitizer alami ini untuk menambahpenghasilan mereka secara ekonomi.

E. Manfaat Kegiatan

Kegiatan pengabdian kepada masyarakat ini diharapkan dapat memberikan manfaat dari sisi pendidikan, sisi nilai tambah, serta memberikan dampak secara keseluruhan. Setiap detil manfaat kegiatan dipaparkan sebagaiberikut:

1) Sisi Pendidikan

Kegiatan pengabdian kepada masyarakat ini diharapkan dapat memberikan edukasi kepada masyarakat RT $27 \mathrm{Gg}$. Sei.Awang Banjarmasin mengenai seluk beluk pandemi virus Covid-19 dan protokol kesehatan yangharus dijalankan sesuai anjuran Pemerintah dan WHO

2) Sisi Nilai Tambah

Kegiatan pengabdian kepada masyarakat ini diharapkan dapat memberikan wacana akan peluang wirausaha yang bisa didapat oleh masyarakat RT $27 \mathrm{di} \mathrm{Gg}$. Sei Awang Banjarmasin. dalam memanfaatkan bahan alami sebagai pengganti bahan kimia untuk menghasilkan hand sanitizer yang penting digunakan selama masa pandemi Covid-19.

3) Dampak secara keseluruhan

Dengan diperolehnya pengetahuan mengenai cara pembuatan hand sanitizer alternative dari bahan alami, selanjutnya masyarakat RT 27 Gg. Sei. Awang Banjarmasin memiliki kemampuan berwirausaha lainnya di tengah situasi pandemi Covid-19. Di masa yang akan datang selama pandemi Covid-19 masih berlangsung maupun sesudahnya, masyarakat dapat menambah bidang wirausaha lainnya, seperti: memproduksi masker yang terbuat dari kain perca danmenjualnya, memproduksi sabun cuci tangan dari bahan alami, maupun memproduksi bahan lainnya yang dapat dimanfaatkan untuk peluang tambahan secara ekonomi. 


\section{TARGET DAN LUARAN}

\section{Sasaran}

Sasaran kegiatan Pengabdian kepada Masyarakat ini adalah masyarakat RT.27 Gg. Sei. Awang Banjarmasin khususnya ibu-ibu rumah tangga \& remaja puteri. Karena situasi pandemi Covid-19 tidak diizinkan untuk mengumpulkan masyarakat dalam jumlah banyak, maka peserta dibatasi untuk tidak lebih dari 30 orang. Ibu rumah tangga dan remaja putri yang menjadi sasaran kegiatan masih berada dalam usia yang produktif agar kegiatan ini dapat tepat sasaran. Berikut ini adalah foto dari peserta kegiatan PKM ini yangdisajikan pada Gambar 2.1.

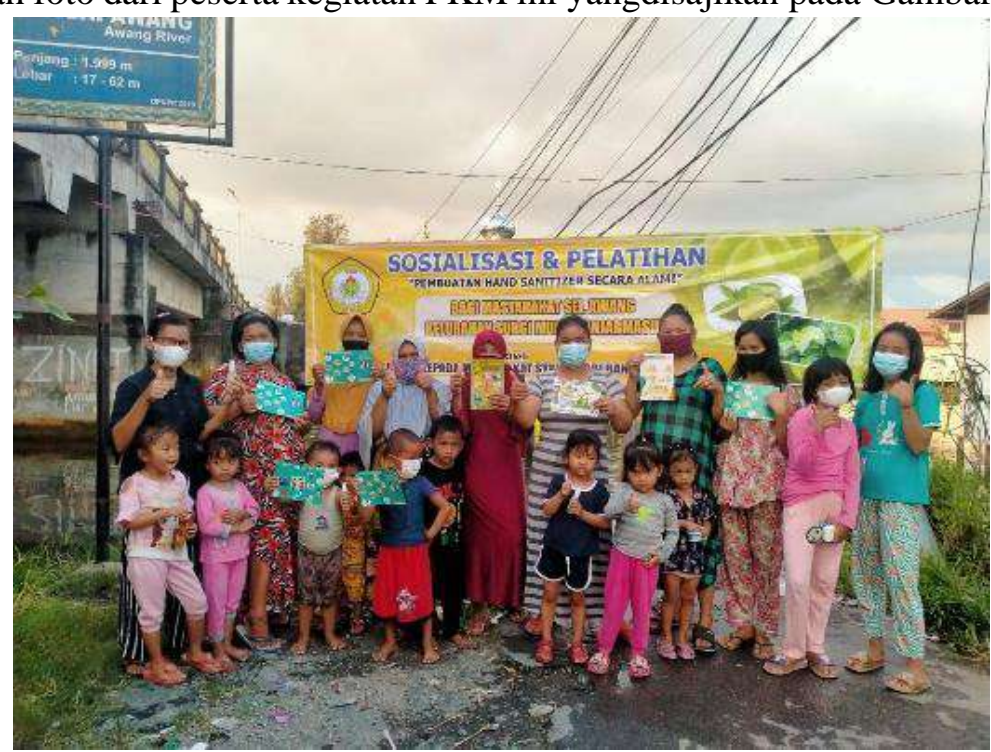

Gambar 2.1. Sasaran Kegiatan Pengabdian Kepada Masyarakat (PKM)

\section{Bentuk Kegiatan}

Bentuk kegiatan pengabdian kepada masyarakat (PKM) ialah berupa sosialisasi dan pelatihan. Adapun metode pelaksanaan kegiatan "Sosialisasi dan Pelatihan Pembuatan Hand Sanitizer Secara Alami dari Daun Sirih dan Jeruk Nipis Bagi Masyarakat Sei. Awang RT. 27 Kelurahan Surgi Mufti Banjarmasin" secara garis besar dapat dilihat dari diagram pada Gambar 2.2. berikut ini.

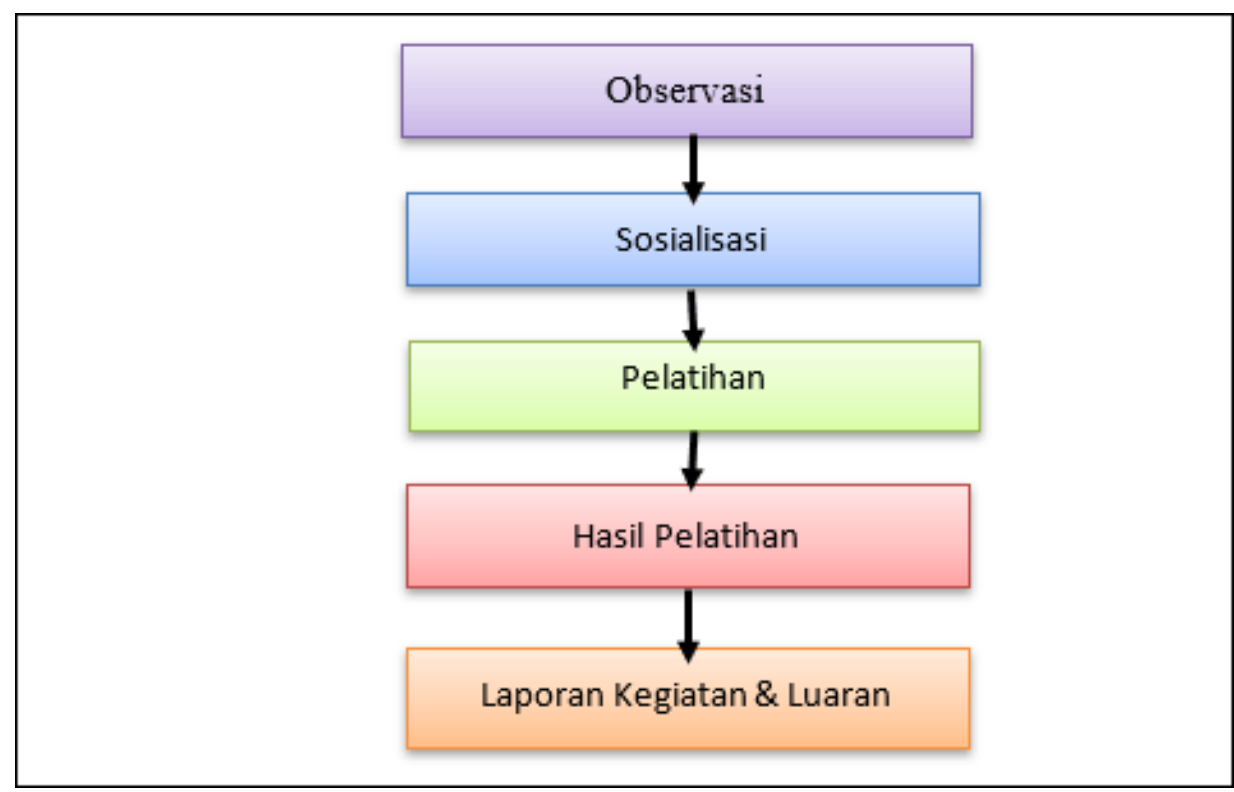

Gambar 2.2. Garis Besar Kegiatan 
Proses pelaksanaan kegiatan PKM ini bisa dilakukan secara offline \& online. Secara offline dengan langsung turun ke lapangan memberikan sosialisasi dan pelatihan. Sedangkan secara online dengan membuat grup WA bagi yang memiliki fasilitas hp android bisa saling berdiskusi \& melakukan pembimbingan terhadap mitra yang kurang mengerti.

Partisipasi mitra dalam kegiatan adalah sebagai peserta kegiatan sosialisasi dan pelatihan pembuatan hand sanitizer secara alami dari daun sirih dan jeruk nipis. Mitra akan mendapat materi sosialisasi serta pelatihan yang diharapkan dapat menjadi ide dan peluang usaha.

Gambaran iptek yang diimplementasikan kepada mitra disajikan secararingkas pada Gambar 2.3 di bawah ini.

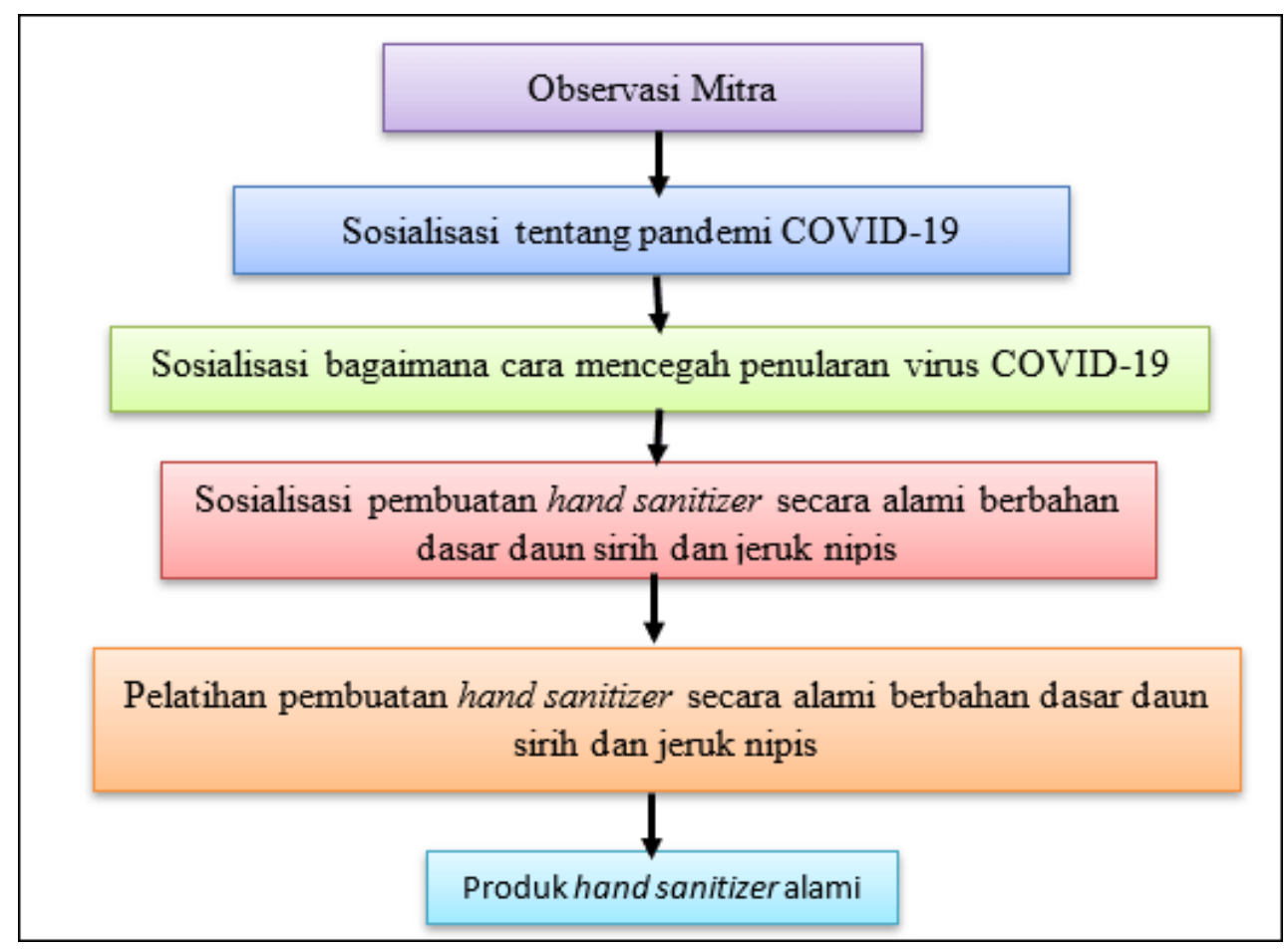

Gambar 2.3. Gambaran Iptek yang Diimplementasikan kepada Mitra.

\section{Target dan Luaran}

Target

Target kegiatan pengabdian kepada masyarakat yang berjudul "Sosialisasi dan Pelatihan Pembuatan Hand Sanitizer Secara Alami dari Daun Sirih dan Jeruk Nipis Bagi Masyarakat Sei. Awang RT. 27 Kelurahan Surgi Mufti Banjarmasin” antara lain:

- Tersampaikannya informasi mengenai bahaya virus covid-19

- Tersampaikannya informasi mengenai protokol kesehatan

- Meningkatnya kesadaran masyarakat untuk menerapkan protokolkesehatan

- Tersampaikannya informasi mengenai adaptasi kebiasaan new normal

- Tersampaikannya informasi mengenai manfaat penggunaan handsanitizer

- Tersampaikannya informasi mengenai cara pembuatan hand sanitizer

- Dihasilkannya produk hand sanitizer hasil praktik peserta kegiatan

\section{Luaran}

Luaran yang dihasilkan dari kegiatan pengabdian kepada masyarakat iniantara lain yaitu:

- Laporan kegiatan pengabdian kepada masyarakat

- Publikasi artikel pengabdian kepada masyarakat pada jurnal nasional tidak terakreditasi.

- Produk hand sanitizer karya masyarakat Sei. Awang RT. 27. 
BAKTI BANUA : Jurnal Pengabdian Kepada Masyarakat

Volume 2 No. 22021

e-ISSN : 2722-3736

p-ISSN : 2722-7529

https:/ / ejurnal.stimi-bjm.ac.id/index.php/BBJM/

\section{METODE PELAKSANAAN}

\section{Persiapan}

Persiapan yang dilakukan dalam kegiatan pengabdian kepada masyarakat yang berjudul "Sosialisasi dan Pelatihan Pembuatan Hand Sanitizer Secara Alami dari Daun Sirih dan Jeruk Nipis Bagi Masyarakat Sei. Awang RT. 27 Kelurahan Surgi Mufti Banjarmasin” antara lain:

1. Membuat perencanaan

Proses perencanaan meliputi identifikasi kebutuhan, identifikasi potensi dan kelemahan yang ada, menentukan jalan keluar dan kegiatan yang akan dilakukan, dan membuat pengorganisasian kegiatan.

2. Melakukan survey lokasi pengabdian kepada masyarakat

Survey lokasi kegiatan pengabdian kepada masyarakat dilakukan untuk menetapkan lokasi kegiatan dan sasaran peserta kegiatan. Jika lokasi kegiatan sesuai maka akan dilanjutkan kegiatan di lokasi tersebut. Tapi jika tidak maka akan dicari alternatif lokasi lainnya yang lebih sesuai dengan tujuan dan sasaran kegiatan pengabdian kepada masyarakat. Namun berdasarkan survey yang dilakukan diketahui bahwa lokasi di Sei. Awang ini sudah tepat sehingga kegiatan PKM dapat dilakukan di lokasi tersebut.

3. Mempersiapkan proposal kegiatan

Setelah didapat hasil dari proses perencanaan maka dilanjutkan dengan mempersiapkan proposal kegiatan untuk diajukan ke bagian P3MP. Jika sudah maka yang dilakukan selanjutnya adalah menunggu keputusan disetujui atau tidaknya proposal tersebut.

4. Mengurus surat izin kegiatan

Setelah proposal kegiatan disetujui maka tahapan berikutnya adalah mengurus surat izin kegiatan di STKIP PGRI Banjarmasin. Surat ini digunakan untuk mengurus perizinan lokasi pengabdian kepada masyarakat.

5. Mengurus perizinan lokasi pengabdian kepada masyarakat

Tim pengabdian mendatangi lokasi sasaran kegiatan dan menemui ketua RT untuk mengurus perizinan lokasi PKM. Jika diizinkan maka kegiatan dapat dilaksanakan.

6. Mengadakan pertemuan awal antara ketua PKM dan peserta

Pertemuan awal ini bertujuan untuk mengetahui gambaran sasaran kegiatan untuk memastikan bahwa kegiatan ini akan tepat sasaran.

7. Menyusun rencana kerja kegiatan pengabdian kepada masyarakat

Rencana kerja kegiatan PKM dibuat untuk memastikan bahwa kegiatan yang dilakukan sesuai dengan tujuan kegiatan dan luaran yang diharapkan.

8. Menetapkan rencana jadwal kerja pengabdian kepada masyarakat

Agar kegiatan terlaksana dan tepat waktu maka diperlukan adanya rencana jadwal kerja pengabdian kepada masyarakat.

9. Menetapkan pembagian kerja diantara ketua tim PKM dan anggota lainnya

Setelah dibuat rencana jadwal kerja penggabdian kepada masyarakat, maka selanjutnya dilakukan pembagian kerja antara ketua dan anggota tim PKM. Dengan adanya rencana jadwal kerja ini maka akan bisa membagi tugas dan siapa yang menjadi penanggung jawabnya.

10. Mempersiapakan bahan dan peralatan yang dibutuhkan untuk pengabdian masyarakat

Guna mendukung kelancaran kegiatan pengabdian kepada masyarakat tentu saja memerlukan adanya bahan dan peralatan yang tepat guna.

\section{Pelaksanaan} masyarakat.

Berikut ini adalah penjelasan mengenai pelaksanaan kegiatan pengabdian kepada

1. Personalia Kegiatan

Personalia kegiatan Pengabdian kepada Masyarakat ini secararinci diuraikan sebagai berikut.

a. Ketua Pelaksana

Nama lengkap

: Dr. Dra. Hj. Rezky Nefianthi, 
BAKTI BANUA : Jurnal Pengabdian Kepada Masyarakat

Volume 2 No. 22021

e-ISSN : 2722-3736

M.Si.NIP

Pangkat/Golongan

IV/aJabatan

Bidang Keahlian

b. Anggota Pelaksana 1

Nama lengkap

NIK

Pangkat/Golongan

IIIcJabatan

Bidang Keahlian

c. Anggota Pelaksana 2

Nama lngkap

M.PdNIK

Pangkat/Golongan

I/IIIbJabatan

Bidang Keahlian

d. Anggota Pelaksana 3

Nama lengkap

NIK

Pangkat/Golongan

IIIbJabatan

Bidang Keahlian

e. Anggota Pelaksana 4

Nama lengkap

NIP

Pangkat/Golongan

IIIcJabatan

Bidang Keahlian

f. Anggota Pelaksana 5

Nama lengkap

M.Kes.NIK

Pangkat/Golongan

Jabatan

Bidang Keahlian
196510151992032004

: Pembina Utama Muda/

: Lektor Kepala

: Pendidikan Biologi

: Rabiatul Adawiyah, M.Pd

070204078

: Penata/

: Lektor

: Pendidikan Biologi

: Nana Citrawati Lestari, S.Si., 130204101

: Penata Muda Tingkat

: Asisten Ahli

: Pendidikan Guru Sekolah Dasar

: Isna Kasmilawati, M.Pd

150101111

: Penata Muda Tingkat I/

: Asisten Ahli

: Pengajaran Guru Sekolah Dasar

: Lagiono, M.P

196610161993031002

: Penata /

: Lektor

: Pengajaran Guru Sekolah Dasar

: Hj. Maryam Agustina, S.Pd., 190502167

: Tenaga Pengajar

: Pengajaran Guru Sekolah Dasar

2. Jadwal dan Tempat Kegiatan

Jadwal kegiatan Pengabdian kepada Masyarakat ini dilaksanakan selama empat hari yaitu pada tanggal 25, 26, dan 27 Mei 2021. Kegiatan ini dilaksanakan dalam 2 bentuk yaitu secara luring dan secara daring. Kegiatan dilaksanakan secara luring selama 2 yaitu hari pertama dan hari ke tiga yakn pada tanggal 25 dan 27 M e i 2021 dengan lokasi kegiatan pelatihan ini bertempat di salah satu rumah warga RT 27 Gg. Sei Awang Banjarmasin. Sementara, kegiatan pelatihan ini dilaksanakan secara daring melalui Grup WA untuk kegiatan di hari ke dua yakni pada tanggal 26 Mei 2021. Selain itu di grup WA juga disampailkan informasi perihal persiapan untuk praktik di hari ke tiga.

3. Tema Kegiatan

Tema kegiatan ini masih terkait dengan pandemi covid-19 yang sudah ahun ke-dua kita alamai. Adapun judul dari kegiatan pengabdian kepada masyarakat ini ialah "Sosialisasi dan Pelatihan Pembuatan Hand Sanitizer Secara Alami dari Daun Sirih dan Jeruk Nipis Bagi Masyarakat Sei. Awang RT. 27 Kelurahan Surgi Mufti Banjarmasin”.

4. Bentuk Kegiatan

Bentuk kegiatan pengabdian kepada masyarakat ini secara rinci diuraikan sebagai berikut.

a. Pada hari pertama pelatihan, sebelum menyampaikan materi. Tim pengabdian terlebih 
dahulu membagiakan masker kepada peserta agar tetap bisa menerapkan protokol kesehatan. Selanjutkan dilakukan enyampaian materi secara lisan oleh tim pengabdian masyarakat mengenai seluk beluk penyebaran virus Covid-19, adaptasi di era new normal, \& cara pencegahan Covid-19. Materi diberikan dalam bentuk brosur sederhana yang dibagikan kepada ibu-ibu rumah tangga \& remaja puteri yang mengikuti kegiatan ini. Brosur berisi mengenai gejala orang yang terpapar virus Covid-19, adaptasi new normal dan protokol kesehatan yang diinstruksikan oleh Pemerintah dan WHO. Selain itu juga disampaikan sedikit informasi mengenai hand sanitizer berbahan daun sirih dan jeruk nipis. Pada hari pertama ini, tanya jawab dilakukan antara ibu-ibu rumah tangga dan tim pengabdian masyarakat untuk memberikan informasi sejelas mungkin mengenai virus Covid-19 dan protokol kesehatan itu sendiri.

b. Pada hari kedua pelatihan, dilakukan penyampaian materi melalui Grup WA. Kegiatan pertama yang dilakukan adalah menyampaikan informasi dasar mengenai proses pembuatan hand sanitizer dari daun sirih dan jeruk nipis. Tim pengabdian kepada masyarakat menjelaskan bahan-bahan, cara pembuatan, dan produk yang dihasilkan. Setelah itu tim pengabdian kepada masyarakat mengirimkan video tutorial dari youtube mengenai langkah membuat hand sanitizer dari daun sirih dan jeruk nipis agar warga bisa melihat dengan jelas tahapan pembuatan hand saitizer berbahan alami tersebut. Di hari kedua ini, ibu-ibu rumah tangga \& remaja puteri berusaha untuk memahami setiap langkah yang ditayangkan di Youtube disertai dengan tanya jawab dengan tim pengabdian kepada masyarakat. Kegiatan dilanjutkan dengan penyampaian informasi tentang peluang wirausaha hand sanitizer melalui ceramah dan tanya jawab melalui grup WA, serta melalui videoyoutube.

c. Pada hari ketiga pelatihan, ibu-ibu rumah tangga \& remaja puteri diminta untuk mempraktikan secara langsung cara membuat hand sanitizer berbahan daun sirih dan jeruk nipis. Proses pembuatan tetap diawasi oleh tim pengabdian masyarakat. Setelah selesai mempraktikkan, mereka diminta untuk menampilkan hasil karya hand sanitizer yang telah mereka buat. Kegitan dilanjutkan dengan refleksi melalui tanya jawab yang dilakukan antara tim pengabdian kepada masyarakat dan ibu-ibu rumah tangga tersebut mengenai kendala yang mereka hadapi, nominal biaya yang mereka keluarkan, serta wacana bila mereka memproduksi hand sanitizer tersebut untuk dijual kembali. Setelah refleksi, tim memberikan souvenir sebagai kenang-kenangan sebagai apresiasi kepada peserta kegiatan karena telah bersedia mengikuti seluruh rangkaian kegiatan pengabdian mulai dari hari pertama hingga hari terakhir dan juga mau mempraktikkan cara pembuatan hand sanitizer berbahan alami.

Secara rinci, jadwal kerja kegiatan Pengabdian kepada Masyarakat diuraikan pada Tabel 3.1 di bawah ini.

Tabel 3.1 Distribusi Materi dan Narasumber Kegiatan

\begin{tabular}{cccc}
\hline Tanggal & Materi & Narasumber & Kegiatan \\
\hline 25 & Pembagian masker & Tim & Membagikan \\
Mei & & & masker (offline)
\end{tabular}


BAKTI BANUA : Jurnal Pengabdian Kepada Masyarakat

Volume 2 No. 22021

e-ISSN : 2722-3736

https://ejurnal.stimi-bjm.ac.id/index.php/BBJM/

\begin{tabular}{|c|c|c|c|}
\hline Tanggal & Materi & Narasumber & Kegiatan \\
\hline \multirow[t]{4}{*}{2021} & $\begin{array}{l}\text { Penjelasan melalui } \\
\text { brosur mengenai seluk } \\
\text { beluk Covid-19 } \\
\text { - Asal mula Covid-19 } \\
\text { - Gejala paparan } \\
\text { Covid-19 } \\
\text { Mencegah paparan } \\
\text { Covid-19 }\end{array}$ & $\begin{array}{c}\text { Hj. Maryam } \\
\text { Agustina, S.Pd., } \\
\text { M.Kes }\end{array}$ & $\begin{array}{c}\text { Ceramah dan } \\
\text { tanya jawab } \\
\text { (offline) }\end{array}$ \\
\hline & $\begin{array}{l}\text { Penjelasan mengenai } \\
\text { adaptasi di era new } \\
\text { normal \& protokol } \\
\text { kesehatan yang } \\
\text { diinstruksikanoleh } \\
\text { Pemerintah dan } \\
\text { WHO }\end{array}$ & $\begin{array}{c}\text { Dr. Hj. Rezky } \\
\text { Nefianthi, M.Si }\end{array}$ & $\begin{array}{c}\text { Ceramah dan } \\
\text { tanya jawab } \\
\text { (offline) }\end{array}$ \\
\hline & $\begin{array}{l}\text { Penjelasan secara lisan } \\
\text { mengenai } \\
\text { hand sanitizer } \\
\text { - Pengertian hand } \\
\text { sanitizer } \\
\text { - Kegunaan hand } \\
\text { sanitizer } \\
\text { - Pentingnya } \\
\text { penggunaan hand } \\
\text { sanitizer }\end{array}$ & $\begin{array}{c}\text { Rabiatul } \\
\text { Adawiyah, M.Pd }\end{array}$ & $\begin{array}{c}\text { Ceramah dan } \\
\text { tanya jawab } \\
\text { (offline) }\end{array}$ \\
\hline & $\begin{array}{l}\text { Penyampaian informasi } \\
\text { contoh produk hand } \\
\text { sanitizer yang dihasilkan } \\
\text { dari jeruk nipis dan daun } \\
\text { sirih }\end{array}$ & $\begin{array}{l}\text { Nana Citrawati } \\
\text { Lestari, S.Si., } \\
\text { M.Pd. }\end{array}$ & $\begin{array}{c}\text { Ceramah dantanya } \\
\text { jawab (offline) }\end{array}$ \\
\hline
\end{tabular}


BAKTI BANUA : Jurnal Pengabdian Kepada Masyarakat

Volume 2 No. 22021

e-ISSN : 2722-3736

p-ISSN : 2722-7529

https://ejurnal.stimi-bjm.ac.id/index.php/BBJM/

\begin{tabular}{|c|c|c|c|}
\hline Tanggal & Materi & Narasumber & Kegiatan \\
\hline $\begin{array}{c}26 \\
\text { Mei } \\
2021\end{array}$ & $\begin{array}{l}\text { Penyampaian informasi } \\
\text { dasar mengenai proses } \\
\text { pembuatan hand sanitizer } \\
\text { dari daun sirihdan jeruk } \\
\text { nipis yang terdiri dari: } \\
\text { - Bahan } \\
\text { dan alat } \\
\text { yang } \\
\text { diperluka } \\
\text { n } \\
\text { - Tahapan-tahapan } \\
\text { pembuatan } \\
\text { - Produk yang } \\
\text { dihasilkan }\end{array}$ & $\begin{array}{c}\text { Rabiatul } \\
\text { Adawiyah, M.Pd }\end{array}$ & $\begin{array}{l}\text { Ceramah dan } \\
\text { tanya jawab } \\
\text { melalui wa grup } \\
\quad(\text { online })\end{array}$ \\
\hline
\end{tabular}

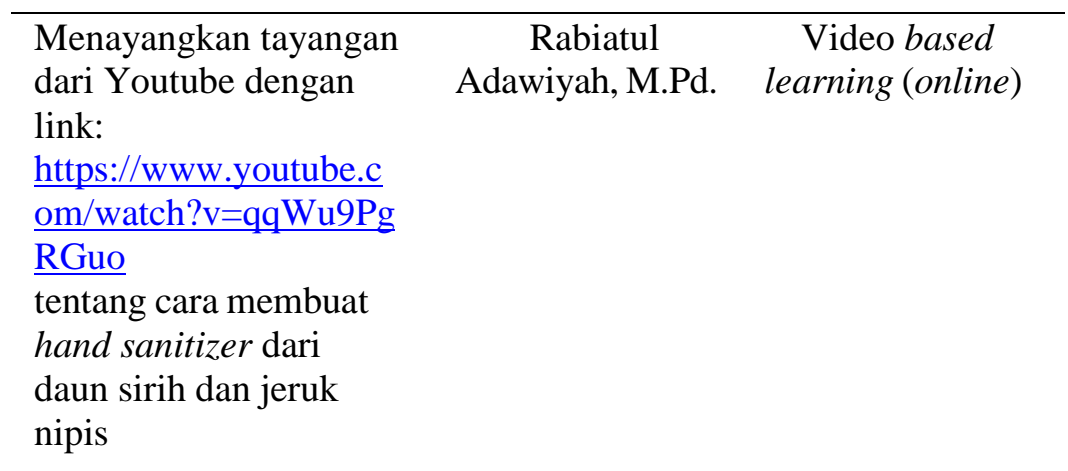

\begin{tabular}{lcc}
\hline Menyampaikan informasi & Lagiono, M.P & Ceramah dan \\
tentang peluang wirausaha & & tanya jawab \\
handsanitizer & (online) \\
dari bahan alami &
\end{tabular}


BAKTI BANUA : Jurnal Pengabdian Kepada Masyarakat

Volume 2 No. 22021

e-ISSN : 2722-3736

https:/ / ejurnal.stimi-bjm.ac.id/index.php/BBJM/

\begin{tabular}{|c|c|c|c|}
\hline Tanggal & Materi & Narasumber & Kegiatan \\
\hline & $\begin{array}{l}\text { Menayangkan tayangan } \\
\text { dari Youtubedengan } \\
\text { link: } \\
\text { https://www.youtube.c } \\
\text { om/watch?v=- } \\
\underline{\text { u} 4 \mathrm{C} 5 \mathrm{hmounI}} \\
\text { mengenaipengalaman } \\
\text { orang lain yang } \\
\text { menjadikan hand } \\
\text { sanitizer sebagai } \\
\text { peluang wirausaha di } \\
\text { tengah pandemi } \\
\text { Covid-19 dan mengapa } \\
\text { hand sanitizer dari } \\
\text { bahan alami dapat } \\
\text { menjadi alternatif } \\
\text { wirausaha ditengah } \\
\text { pandemi Covid-19. }\end{array}$ & $\begin{array}{c}\text { Isna } \\
\text { Kasmilawati, } \\
\text { M.Pd }\end{array}$ & $\begin{array}{c}\text { Video Based } \\
\text { Learning (online) }\end{array}$ \\
\hline
\end{tabular}

\begin{tabular}{|c|c|c|c|}
\hline \multirow[t]{2}{*}{$\begin{array}{c}27 \\
\text { Mei } \\
2021\end{array}$} & $\begin{array}{l}\text { Praktik pembuatan hand } \\
\text { sanitizer oleh warga }\end{array}$ & $\begin{array}{c}\text { Rabiatul } \\
\text { Adawiyah, M.Pd. } \\
\text { dan Nana } \\
\text { Citrawati Lestari, } \\
\text { S.Si., M.Pd. }\end{array}$ & Praktik (offline) \\
\hline & $\begin{array}{l}\text { Penampilan hasil praktik } \\
\text { warga }\end{array}$ & $\begin{array}{c}\text { Rabiatul } \\
\text { Adawiyah, M.Pd. } \\
\text { dan Nana } \\
\text { Citrawati Lestari, } \\
\text { S.Si., M.Pd. }\end{array}$ & Presentasi \\
\hline Tanggal & Materi & Narasumber & Kegiatan \\
\hline & Refleksi & $\begin{array}{c}\text { Rabiatul } \\
\text { Adawiyah, M.Pd. } \\
\text { dan Nana } \\
\text { Citrawati Lestari, } \\
\text { S.Si., M.Pd. }\end{array}$ & Tanya jawab \\
\hline & Pemberian apresiasi & $\begin{array}{c}\text { Rabiatul } \\
\text { Adawiyah, M.Pd. } \\
\text { dan Nana } \\
\text { Citrawati Lestari, } \\
\text { S.Si., M.Pd. }\end{array}$ & $\begin{array}{c}\text { Penyerahan kuota } \\
\text { dan souvenir }\end{array}$ \\
\hline
\end{tabular}


BAKTI BANUA : Jurnal Pengabdian Kepada Masyarakat

Volume 2 No. 22021

e-ISSN : 2722-3736

p-ISSN : 2722-7529

https://ejurnal.stimi-bjm.ac.id/index.php/BBJM/

\section{Evaluasi Program dan Rencana Keberlanjutan Program}

Untuk mengevaluasi apakah kegiatan sosialisasi dan pelatihan yang dilakukan dapat memberikan informasi dan pemahaman kepada peserta kegiatan maka di beberapa tahapan kegiatan juga diselingi dengan diskusi atau tanya jawab. Selain itu di akhir kegiatan tim pengabdian masyarakat juga memberikan pandangan bahwa hand sanitizer alami ini cukup mungkin menjadi peluang wirausaha bagi mereka karena bahan bakunya cukup murah. Pemasarannya pun bisa melalui koperasi, toko, kios, maupun dijual secara daring dengan memanfaatkan media social yang bisa dikelola perorangan maupun perkelompok.

Berikut ini adalah hasil evaluasi pelaksanaan program dan keberlanjutan program di lapangan setelah kegiatan PKM selesai dilaksanakan.

a. Program sudah terlaksana sesuai jadwal kerja yang telah dibuat

b. Semua informasi sudah diberikan sesuai dengan rencana kerja kegiatan

c. Peserta kegiatan PKM mampu mempraktikkan pembuatan hand sanitizer sesuai petunjuk dan arahan yang diberikan

d. peserta kegiatan PKM telah menghasilkan produk hand sanitizer berbahan daun sirih dan jeruk nipis

e. Tim PKM akan kembali ke lokasi kegiatan untuk memantau keberlanjutanprogram di lapangan.

f. Tim PKM akan mempublikasikan hasil kegiatan ke dalam bentuk artikeljurnal PKM.

\section{HASIL DAN PEMBAHASAN}

\section{Hasil}

Hasil kegiatan pengabdian kepada masyarakat dengan tema Sosialisasi \& Pelatihan Pembuatan Hand sanitizer dari Daun Sirih dan Jeruk Nipis di RT 27, Gg. Sei. Awang Banjarmasin yang dilaksanakan pada tanggal 25, 26, dan 27 Mei 2021 ini sesuai dengan tujuan yang diharapkan. Adapun hasil kegiatan yang diperoleh sebagai berikut:

1. Sosialisasi hari pertama, 25 Mei 2021 secara offline berlangsung tertib danlancar.

a. Secara umum masyarakat mendapatkan informasi yang benar \& pemahaman tentang seluk beluk covid-19 seperti asal mula covid-19, cara penularan \& gejala-gejala yang muncul serta cara pencegahannya.

b. Masyarakat menjadi lebih mengetahui cara-cara beradaptasi kebiasan baru atau new normal pandemi covid-19 serta peduli untuk menerapkan protokol kesehatan yang diinstruksikanoleh Pemerintah dan WHO. Hal ini terlihat dimana mereka yang sebelumnya tiak terbiasa dengan memakai masker menjadi mulai terbiasa memakai masker \& membawa hand sanitizer jika bepergian.

c. Masyarakat menjadi lebih mengetahui informasi yang jelas tentang pengertian, kegunaan, dan pentingnya menggunakan hand sanitizer. Hal ini bisa kami lihat dari perhatian mereka menyimak penyampaian materi oleh narasumber \& aktif diskusi / bertanya jawab saat sosialisasi berlangsung. Mereka juga ikut mempraktekan cara menggunakan hand sanitizer yang benar saat tim kami mendemonstrasikan cara penggunaanhand sanitizer yang benar.

d. Masyarakat sangat antusias saat tim kami menyampaikan informasi contoh produk hand sanitizer yang dihasilkan dari jeruk nipis dan daun sirih. Mereka sangat senang saat tim kami membagikan sampel produk hand sanitizer tersebut kepada peserta sosialisasi di hari pertama \& langsung mencoba menggunakannya. Peserta sosialisasi juga ada yang bertanya ingin mengetahui bagaimana cara membuatnya hand sanitizertersebut.

2. Sosialisasi hari kedua, tanggal 26 Mei 2021 secara online berlangsung cukup lancar.

a. Masyarakat khususnya remaja puteri yang memiliki handpon\& nomor WA bersedia untuk bergabung digrup sosialisasi \& pelatihan pembuatan hand sanitizer secara alami. Mereka mengetahui penyampaian informasi dasar mengenai proses pembuatan hand sanitizer dari daun sirih dan jeruk nipis yang terdiri dari: bahan dan alat yang diperlukan, tahapan-tahapan pembuatan, \& produk yang dihasilkan. Mereka merasa mudah mendapatkan bahan-bahannya \& cara membuatnya tidak begitu sulit. Mereka juga senang mendapatkan kiriman video cara 
pembuatan hand sanitizer secara alami, namun hanya sebagian peserta yang selesai menonton semua video yang dikirimkan lewat WA. Peserta juag bersedia untuk menginformasikan kembali apa yang sudah diperoleh ke orang tuanya, sanak saudara, teman-teman \& masyarakat sekitar tempat tinggal mereka .Peserta grup WA merasa senang \& mengetahui informasi tentang peluang wirausaha hand sanitizer dari bahan alami.

b. Peserta menyimak dengan baik tayangan video dari youtube yang tim kami kirimkan mengenai pengalaman orang lain yang menjadikan hand sanitizer sebagai peluang wirausaha di tengah pandemi Covid-19 dan mengapa hand sanitizer dari bahan alami dapat menjadi alternatif wirausaha di tengah pandemi Covid-19. Diantara peserta ada yang merasa tertarik untuk mencobanya.

3. Pelatihan hari ketiga, tanggal 27 Mei 2021 secara offline berlangsung cukup lancar.

a. Peserta pelatihan khususnya ibu-ibu rumah tangga \& remaja puteri merasa antusias \& semangat mengikuti kegiatan praktek pembuatan hand sanitizer secara alami dari daun sirih \& jeruk nipis dari awal sampi akhir kegiatan dengan turut memakai masker, menjaga jarak \& mencusi tangan di sela-sela awal \& akhirtahapan pembuatan hand sanitizer.

b. Peserta pelatihan juga semangat untuk segera menampilkan hasil produk yang mereka buat sendiri yang akhirnya mereka berhasil bisa mempraktekan cara membuat hand sanitizer secara alami daridaun sirih \& jeruk nipis dengan baik.

c. Peserta pelatihan praktek membuat produk hand sanitizer merasa gembira \& berterimakasih telah diberikan souvenir \& tambahan kouta internet sebagai bentuk apresiasi dari kami selaku tim PKM.

\section{Pembahasan}

Secara umum kegiatan pengabdian kepada masyarakat dengan tema Sosialisasi \& Pelatihan Pembuatan Hand sanitizer dari Daun Sirih dan Jeruk Nipis yang telah dilaksanakan pada tanggal 25, 26, dan 27 Mei 2021 berjalan tertib, aman, dan lancar. Hal ini terlihat dari sambutan yang baik \& antusiasme ibu-ibu rumah tangga \& remaja puteri di RT 27, Gg. Sei. Awang Banjarmasin. Mereka berkenan meluangkan waktunya untuk mengikuti kegiatan. Mereka juga cukup antusias menyimak \& aktif bertanya ketika tim pengabdian kepada masyarakat memberikan sosialisasi \& pelatihan bagaimana menghasilkan hand sanitizer dari bahan alami serta potensi wirausaha yang bisa didapat untuk menambah penghasilan ekonomi mereka di masa pandemi Covid-19 ini.

Kegiatan sosialisasi dan pelatihan yang kami laksanakan ada secara offline \& online. Secara offline tim kami langsung mendatangi ke lokasi pengabdian bertempat disalah satu rumah warga yaitu Ibu Ainah berusia kurang lebih 51 tahun selaku ibu rumah tangga yang memiliki keahlian sebagai tukang urut atau pijat . Keadaan di rumah beliau sangat strategis untuk melaksanakan kegiatan langsung di masa pandemi sekarang. Kami masih bisa mengatur jarak peserta yang mengikuti kegiatan sekitar 10-15 orang. Dan berdasarkan informasi beliau untuk kegiatan berkumpul warga saat ada acara baik dari salah satu warga ataupun dari dinas intansi tertentu bertempat di rumah beliau.

Pada hari pertama 25 Mei 2021, sebelum kegiatan sosialisasi dimulai salah satu tim kami Wiwi Rahmawati sudah siap membagikan masker gratis kepada setiap peserta yang datang. Satu per satu warga yang datang ke tempat kegiatan kebanyakan belum memakai masker, hanya sebagian warga saja yang memakai masker. Mereka belum terbiasa dengan memakai masker ketika berada di lingkungan tempat tinggal mereka sendiri. Sebagian memakai masker ketika mau bepergian jauh ke luar lingkungan temapt tinggal mereka, seperti ke sekolah, ke pasar \& ketika berjalan-jalan jauh saja. Namun ketika tim kami membagikan masker, mereka sudah paham dan langsung memakainya. Masker yang kami bagikan ada untuk dewasa dan khusus anak-anak karena ibu-ibu yang memiliki anak balita biasanya anak- anaknya pasti ikut ke mana orang tuanya akan pergi. Adapun kegiatan pembagian masker tersebut bisa dilihat pada Gambar 4.1 di bawah ini. 


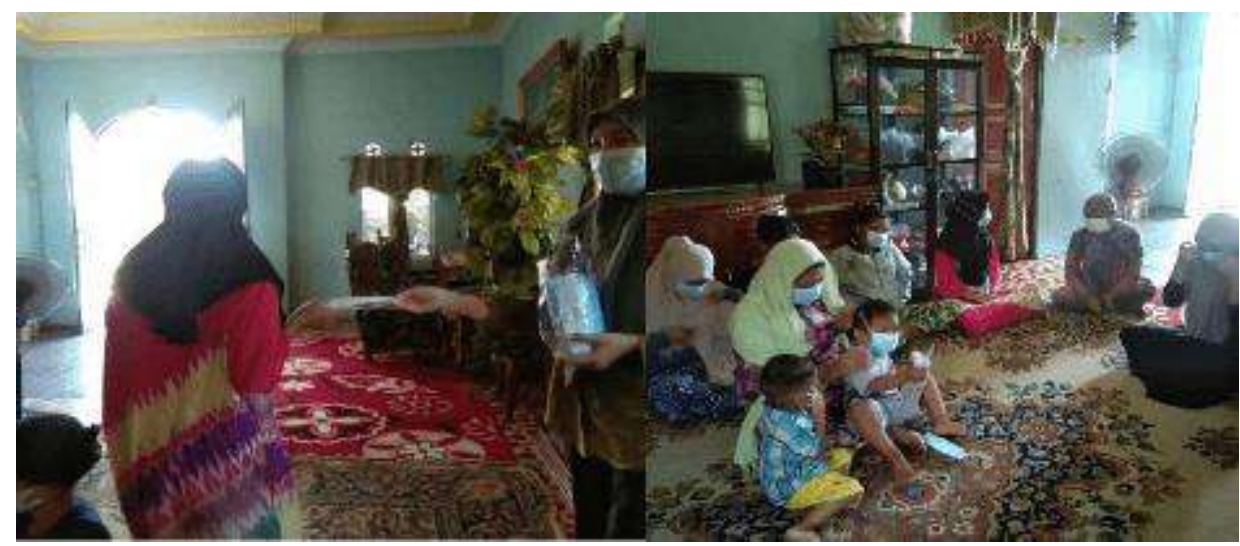

Gambar 4.1 Pembagian Masker oleh Tim PKM

Kegiatan sosialisasi di hari pertama ini, ada 3 kegiatan yang disampaikan oleh tim secara bergiliran. Sosilisasi pertama disampaikan oleh Ibu Hj. Maryam Agustina S.Pd.,Kes. tentang seluk beluk covid-19. Para peserta sangat senang \& antusians mendengarkan pemaparan materi dari narasumber. Tim membagikan poster/ brosur yang berkaitan dengan isi materi sosialisasi semua peserta \& menyerahkan kesalah satu perwakilan peserta untuk dibagikan ke warga yang tidakbisa ikut kegiatan secara langsung. Adapun materi yang disampaikan bisa dilihat pada Gambar 4.2 di bawah ini.

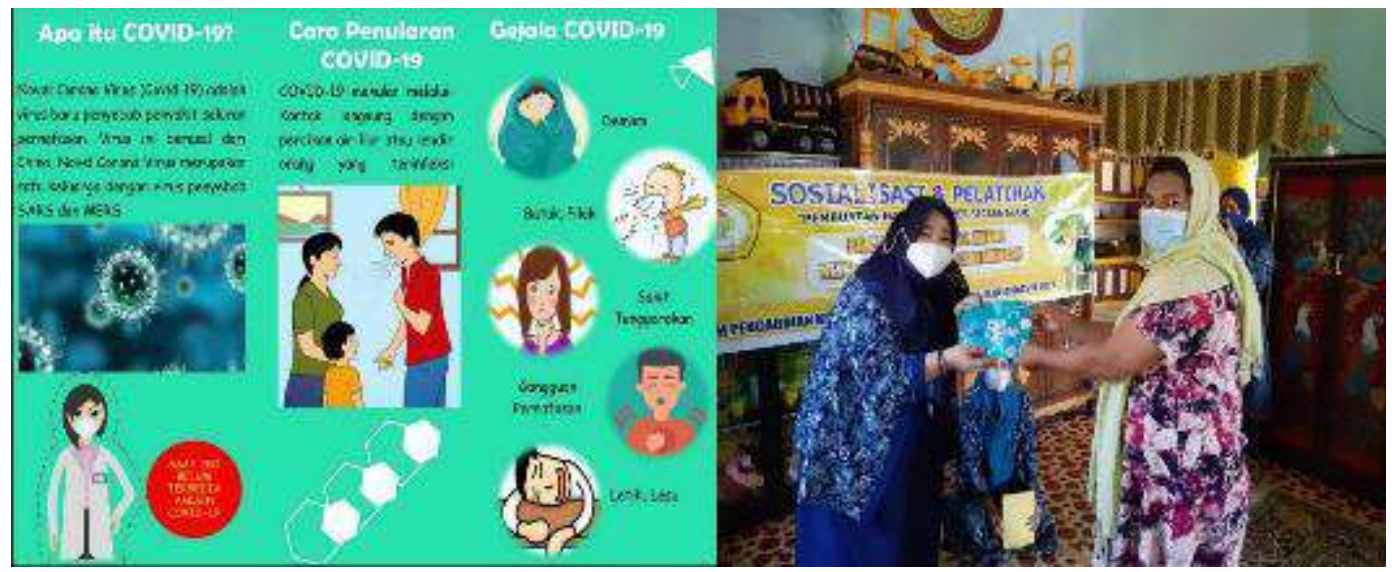

Gambar 4.2 Penyerahan Brosur Materi oleh Ibu Hj. Maryam Agustina, S.Pd., M.Pd

Sosialisasi kedua disampaikan oleh Ibu Dr. Hj. Nefianti, M.Si., tentang Adaptasi Kebiasaan Baru atau New Normal. Beliau menjelaskan kepada peserta untuk wajib memakai masker, menjaga jarak, mencuci tangan dengan sabun, membawa hand sanitizer, jangan bersalaman /say hello saja, duduk ditempat yang tidak diberi tanda silang, setibanya di rumah langsung mandi, Balita \& lansia sebaiknya di rumah saja, jika sedang flu atau sakit di rumah saja, makan makanan bergizi, rajin olah raga serta sebaiknya gunakan uang elektronik kalau diantara mereka ada aplikasinya.

Peserta menyimak dengan baik semua informasi yang disampaikan dan setelah selesai diskusi narasumber menyerahkan poster materi yang disampaikan tadi kepada salah satu perwakilan peserta untuk dibagikan ke warga yang tidak bisa berhadir. Berikut maateri \& penyerahan brosur bisa dilihat pada Gambar 4.3di bawah ini. 


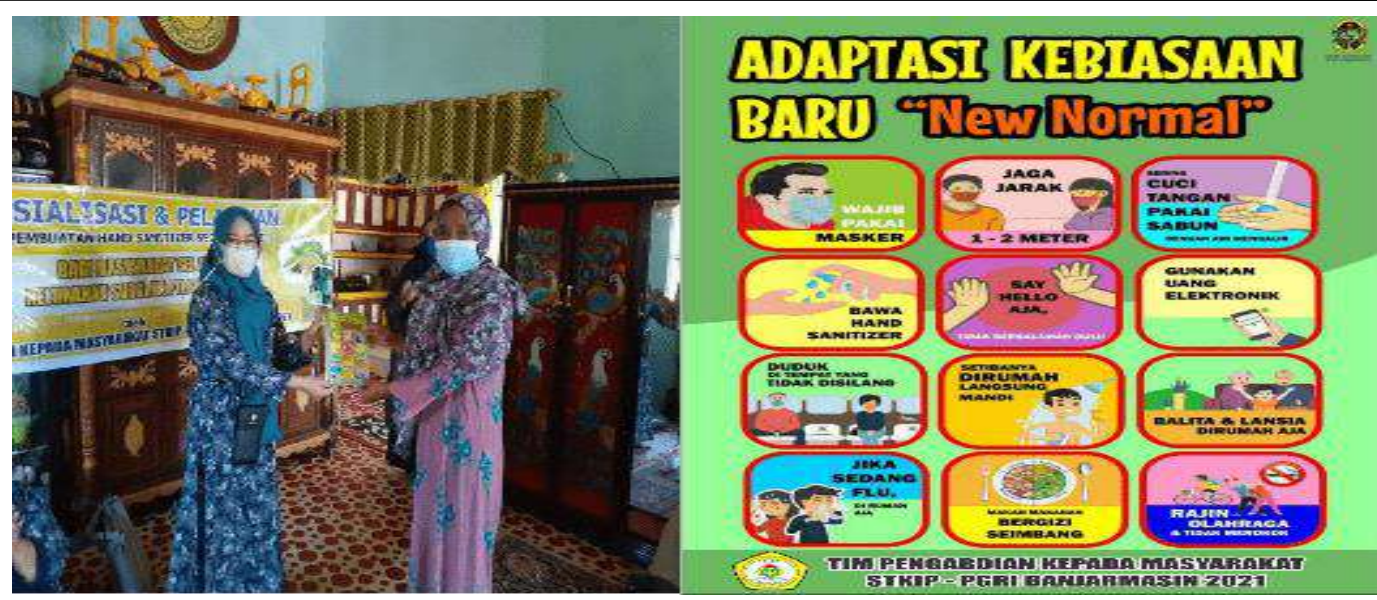

Gambar 4.3 Penyerahan Poster Materi oleh Ibu Dr. Hj. Rezky Nefianti, M.Si

Ibu-ibu rumah tangga \& remaja puteri cukup lancar menjawab pertanyaan yang dilontarkan oleh tim pengabdian masyarakat bahwa virusCovid-19 menyerang saluran pernafasan atas, cukup menular, dan dapat menyebabkan kematian. Untuk mencegah paparan virus ini, Pemerintah dan juga WHO menginstruksikan masyarakat untuk konsisten menerapkan protokol kesehatan dalam kehidupan sehari-hari. Tim pengabdian kepada masyarakat menjelaskan kepada ibu-ibu rumah tangga bagaimana konsep protokol kesehatan yang harus dijalankan. Para peserta menyimak dengan baik setiap paparan dari tim pengabdian kepada masyarakat mengenai protokol kesehatan walaupun mereka juga sudah mengetahuinya dari tayangan televisi dan media sosial.

Pada sesi tanya jawab pada pelatihan hari pertama ini, beberapa ibu rumah tangga mengatakan bahwa mereka belum terbiasa memakai masker saat beraktivitas Di luar rumah. Sebagian dari mereka mengatakan bahwa mereka sulit bernafas jika harus memakai masker, terutama ibu-ibu yang sudah menginjak usia tua. Ditambah lagi dengan mata pencaharian mereka yang mayoritas sebagai petani yang bekerja di ladang tanpa kerumunan, maka semakin sulit bagi mereka untuk membiasakan diri memakai masker. Masker hanya dipakai seperlunya ketika mereka harus beraktivitas jauh dari rumah. Menanggapi hal tersebut, tim pengabdian kepada masyarakat memberikan edukasi dan pemahaman kepada ibu- ibu rumah tangga bahwa penggunaan masker akan mencegah penyebaran dan penularan virus lebih efektif, terutama saat berbicara dengan orang lain. Memakai masker sebagai kebiasaan baru masyarakat perlu ditumbuhkan untuk melindungi mereka sepanjang dan sesudah pandemi Covid-19 ini.

Kegiatan di hari pertama kemudian dilanjutkan oleh Ibu Rabiatul Adawiyah, M.Pd \& Nana Citrawati lestari, S.Si., M.Pd dengan penyampaian informasi dasar mengenai hand sanitizer. Informasi tentang hand sanitizer sebagai salah satu benda yang diperlukan untuk tetap menerapkan protokol kesehatan ketika berada di luar rumah. Selain itu tim juga menjelaskan apa itu hand sanitizer, kegunaan hand sanitizer, dan pentingnya penggunaan hand sanitizer. Selain memberikan penjelasan mengenai hand sanitizer dan pentingnya penggunaan hand sanitizer ini pada saat keluar rumah, tim pengabdian kepada masyarakat juga memberikan penjelasan mengenai alternatif membuat hand sanitizer dari bahan alami. Hand sanitizer yang sesungguhnya terbuat dari bahan kimia berupa60\%- 80\% alcohol dapat digunakan sepanjang benda tersebut tersedia di pasaran. Akan tetapi, bila tidak tersedia di pasaran, maka alternative penggantinya adalahtetap menggunakan hand sanitizer tersebut tetapi terbuat dari bahan non-kimia yang dapat dibuat sendiri dirumah. Salah satu bahan non-kimia yang dapat digunakan untuk membuat hand sanitizer adalah daun sirih dan jeruk nipis.

Peserta menyimak dengan baik informasi yang disampaikan oleh ttim PKM. Mereka juga turut aktif memperagakan langkah penggunaan hand sanitizer yang benar. Adapun materi kegiatan bisa dilihat pada Gambar $4.4 \& 4.5$ di bawah ini. 


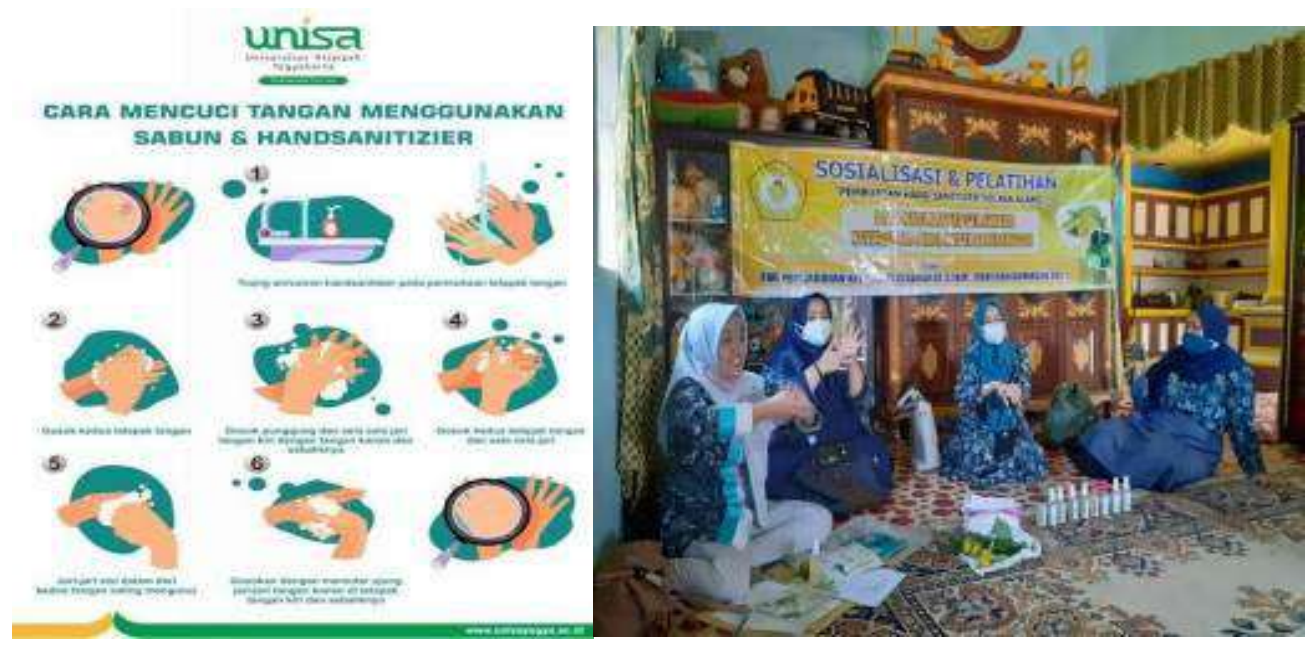

Gambar 4.4. Penyampaian Informasi Materi oleh Ibu Rabiatul Adawiyah, M.Pd

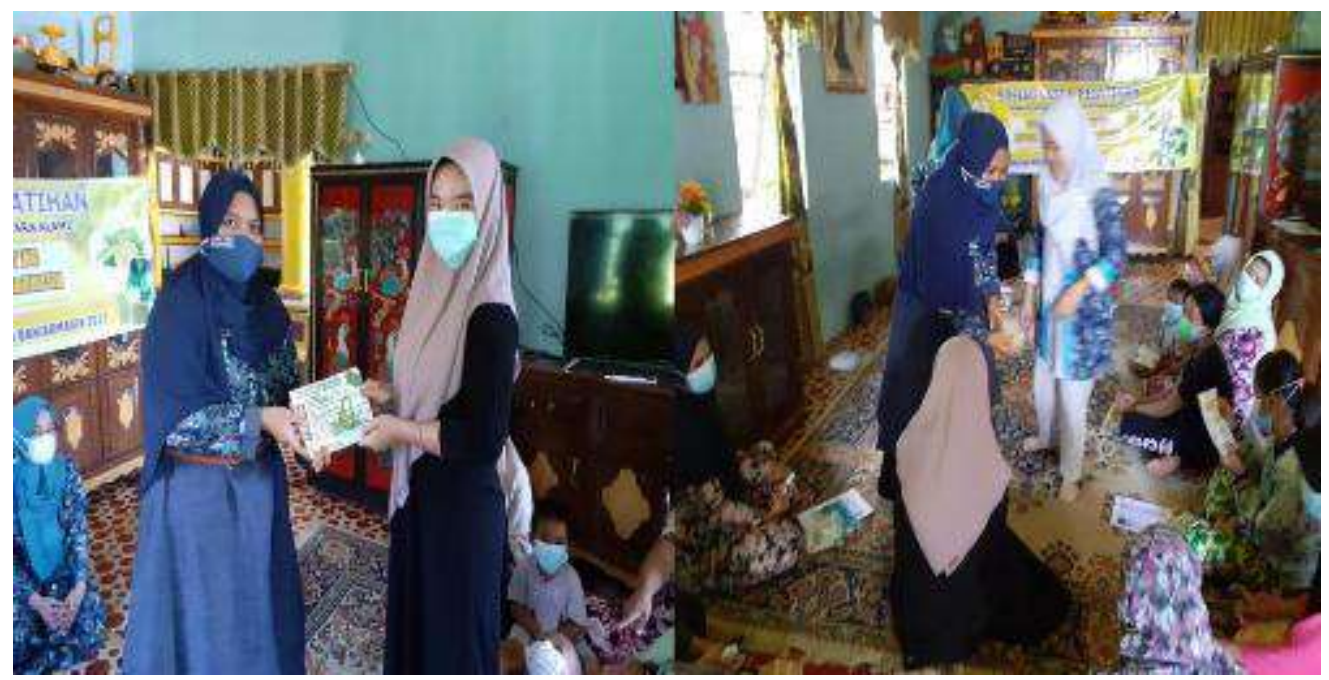

Gambar. 4.5 Penyerahan Poster \& Produk oleh Ibu Nana Citrawati Lestari, S.Si.,M.Pd

Pada hari ke dua 26 Mei 2021, sosialisasi tidak diadakan tatap muka dengan ibu-ibu rumah tangga dan remaja yang menajadi peserta kegiatan ini seperti hal nya pertemuan pertama. Pandemi Covid-19 tidak memungkinkan bagi tim pengabdian kepada masyarakat untuk selalu mengadakan kegiatan yang memerlukan kerumunan, sehingga disepakati bahwa lanjutan pelatihan ini akan dilaksanakan melalui grup WA secara daring. Kegiatan penyampaian informasi melalui grup WA dilakukan oleh tim pengabdian kepada masyarakat menggunakan bahasa yang sederhana dikarenakan mengandung istilah asing agarlebih mudah dipahami oleh ibu-ibu rumah tangga.

Kegiatan pertama yang dilakukan pada pelatihan hari ke dua adalah menyampaikan informasi dasar mengenai proses pembuatan hand sanitizer dari daun sirih dan jeruk nipis. Tim pengabdian kepada masyarakat menjelaskan bahan-bahan, cara pembuatan, dan produk yang dihasilkan. Setelah itu tim pengabdian kepada masyarakat mengirimkan video tutorial dari youtube mengenai langkah membuat hand sanitizer dari daun sirih dan jeruk nipis agar warga bisa melihat dengan jelas tahapan pembuatan hand saitizer berbahan alami tersebut. Di hari kedua ini, ibu-ibu rumah tangga \& remaja puteri berusaha untuk memahami setiap langkah yang ditayangkan di Youtube disertai dengan tanya jawab dengan tim pengabdian kepada masyarakat. Kegiatan dilanjutkan dengan penyampaian informasi tentang peluang wirausaha hand sanitizer melalui ceramah dan tanya jawab melalui grup WA, serta melalui video youtube.

Tim pengabdian kepada masyarakat menjelaskan cara membuat hand sanitizer dari daun 
sirih dan jeruk nipis yang dilengkapi dengan video tutorial dari Youtube agar lebih mudah dipahami. Setelah video tayangan dari Youtube selesai ditampilkan, tim pengabdian masyarakat memberikan penjelasan tambahan dengan menggunakan bahasa yang sederhana sehingga ibu-ibu rumah tangga terbantu memahami langkah-langkah pembuatan hand sanitizer tersebut. Bahan dan alat yang diperlukan untuk membuat hand sanitizer alami sangat sederhana. Beberapa helai daun sirih direbus dan disaring, kemudian ditambahkan perasan air jeruk nipis. Setelah semuanya dilakukan, campuran kedua bahan tersebut dimasukkan ke dalam botol dan ditutup rapat. Cairan yang sudah dimasukkan ke dalam botol tersebut dituangkan ke telapak tangan untuk mematikan kuman dan virus sesuai kebutuhan.

Pada hari ketiga kegiatan pelatihan, tim pengabdian kepada masyarakat kembali datang ke lokasi untuk melihat langsung kegiatan praktik yang dilakukan oleh peserta kegiatan. Setelah itu mereka diminta menunjukkan hasil produk hand sanitizer yang mereka buat. Ibu-ibu rumah tangga \& remaja puteri pun kemudian menunjukkan hasil praktik pembuatan hand sanitizer dari daun sirih dan jeruk nipis yang sudah mereka lakukan. Kegiatan tersebut bisa dilihat pada Gambar 4.6 berikut.

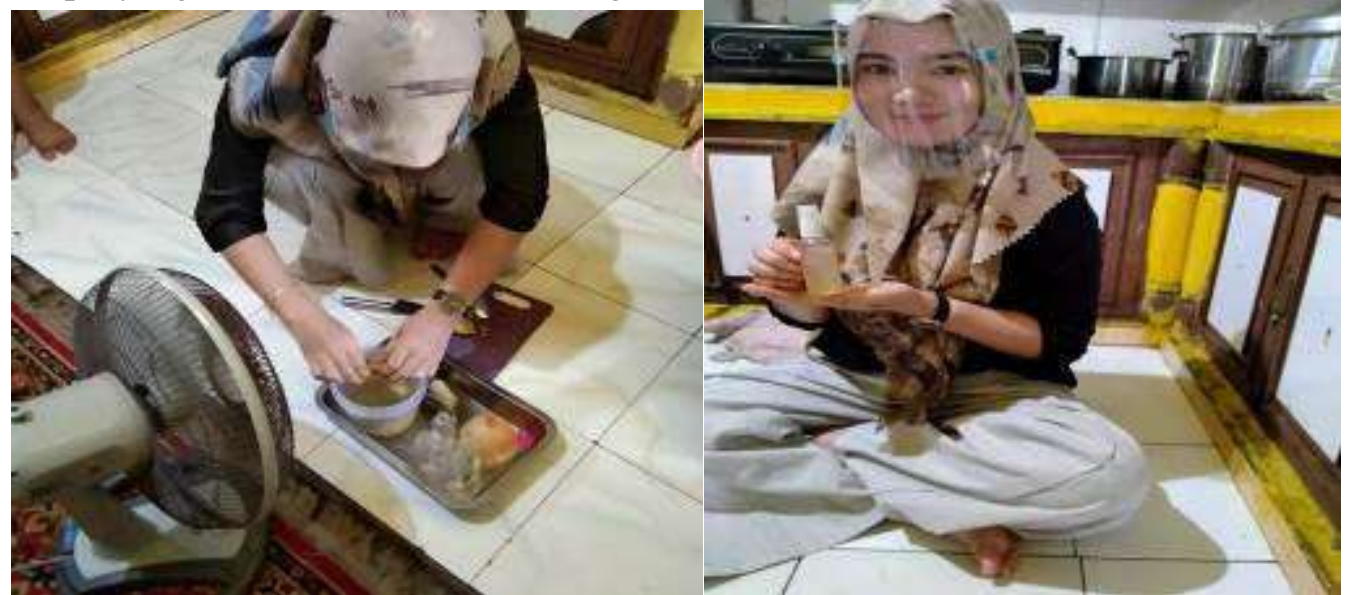

Gambar 4.6 Peserta Pelatihan Membuat Produk Hand Sanitizer Alami.

Tim pengabdian kepada masyarakat cukup senang dengan antusiasme para ibu-ibuini yang menunjukkan bahwa dalam situasi pandemi Covid-19 seperti ini mereka masih mau belajar bersamasama untuk menerapkan protokol kesehatan dengan membuat alternatif bahan untuk dimanfaatkan sebagai pembunuh kuman. Sebagai wujud apresiasi atas antusiasme mereka, tim memberikan souvenir kepada peserta kegiatan yang bisa dilihat pada Gambar 4.7 berikut.

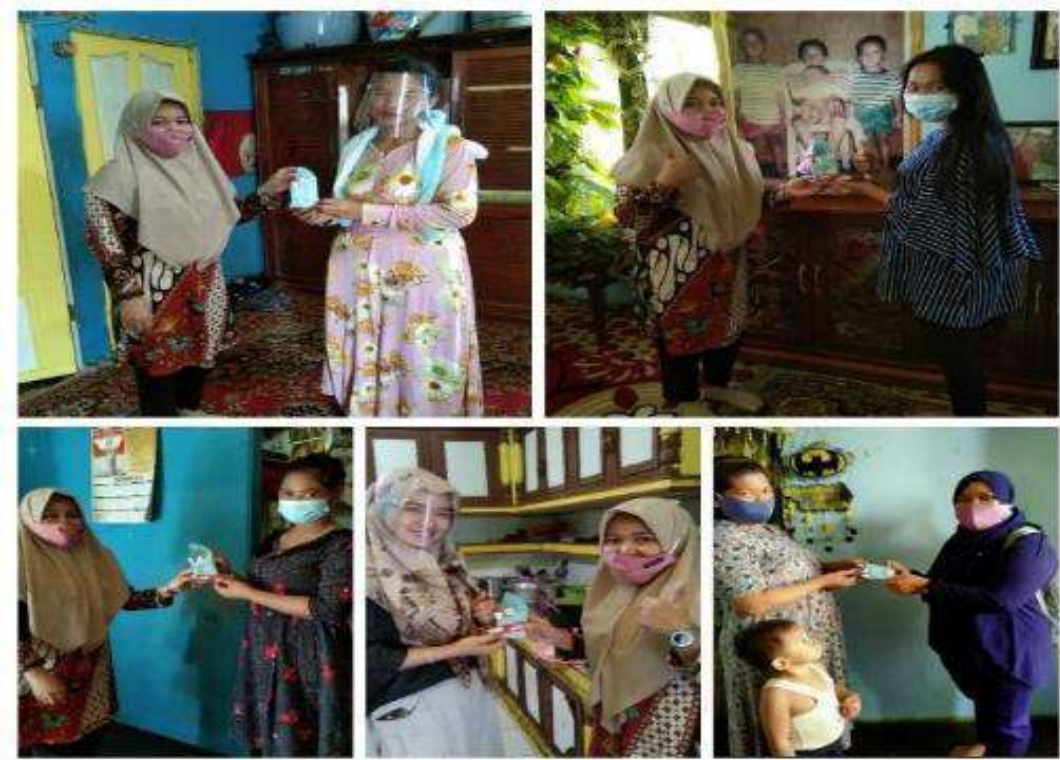

Gambar 4.7 Penyerahan Souvenir \& Paket Kouta Internet 
BAKTI BANUA : Jurnal Pengabdian Kepada Masyarakat

Volume 2 No. 22021

e-ISSN : 2722-3736

p-ISSN : 2722-7529

https://ejurnal.stimi-bjm.ac.id/index.php/BBJM/

Ibu-ibu rumah tangga yang telah mempraktikkan pembuatan hand sanitizer dari jeruk nipis dan daun sirih tidak mendapat kendala apapun saat mempraktikkan. Daun sirih dan jeruk nipis cukup mudah didapat di pasar tradisional, sehingga mereka tidak memiliki kendala dalam hal mendapatkan bahan bakunya. Beberapa ibu-ibu rumah tangga yang lain tidak mempraktikkan pembuatan hand sanitizer ini dengan alasan tidak sempat karena harus mengurus rumah tangga maupun membantusuami bekerja. Tim pengabdian kepada masyarakat pun memaklumi hal ini dan tidak mempermasalahkannya. Semangat mereka yang mau bersama-sama belajar seperti ini patut dihargai dan diapresiasi.

Tim pengabdian masyarakat memberikan pandangan bahwa hand sanitizer alami ini cukup mungkin menjadi peluang wirausaha bagi mereka karena bahan bakunya cukup murah. Pemasarannya pun bisa melalui koperasi, toko, kios, maupun dijual secara daring dengan memanfaatkan media sosial yang bisa dikelola perorangan maupun perkelompok.

Tahap evaluasi merupakan tahapan terakhir dalam kegiatan pengabdian kepada masyarakat ini. Pada tahap ini dilakukan dengan cara : a) menilai tingkat keaktivan peserta dalam kegiatan sosialisasi dan pelatihan. b) menilai tingkat kehadiran peserta selama kegiatan sosialisasi dan pelatihan. c) menilai seberapa banyak peserta pelatihan yang mampu mempraktekan atau membuat hand sanitizer secara alami. Menutup kegiatan pelatihan ini pada hari terakhir, tim pengabdian kepada masyarakat juga menyampaikan bahwa pandemi Covid-19 yang saat ini masihterjadi menyebabkan banyak sekali perubahan dalam tatanan pola hidup masyarakat. Memakai masker, menjaga jarak saat berada di keramaian, mencuci tangan sesering mungkin dengan sabun, serta menggunakan hand sanitizer bila berada dalam kondisi jauh dari air mengalir, memang sulit sekali untuk membiasakannya. Perlu komitmen dan kesabaran dari masing-masing masyarakat untuk melakukannya, terutama bila mengingat bahwa virus Covid-19 ini tergolong virus baru yang belum diketemukan obatnya dan setiap manusia memiliki resiko yang sama untuk terpapar. Oleh karena itu, penting sekali selalu menerapkan protokol kesehatan sesuai anjuran Pemerintah dan WHO dalam setiap aspek kehidupan masyarakat.

Terlepas dari situsi pandemi Covid-19 ini, tentunya tim pengabdian kepada masyarakat mengajak para ibu rumah tangga ini untuk tetap bersemangat. Roda ekonomi memang harus tetap berputar demi menjaga perekonomian secara nasional tetap stabil. Menangkap peluang wirausaha dari situsi pandemi ini bisa menjadi salah satu upaya dan pemikiran untuk menjaga roda perekonomian masyarakat tetap berjalan. Tentunya wirausaha yang kelak dijalankan pun juga menerapkan protokol kesehatan yang standar, sehingga masyarakat bersama-sama saling menjaga diri di masa pandemi Covid-19 yang masih berlangsung hingga saat ini.

\section{PENUTUP}

\section{Simpulan}

Berdasarkan hasil dan pembahasan pada bagian sebelumnya dapat disimpulkan bahwa kegiatan pengabdian kepada masyarakat dengan tema Sosialisasi \& Pelatihan Pembuatan Hand sanitizer dari Daun Sirih dan Jeruk Bagi Masyarakat RT. 27 Gg. Sei. Awang Kelurahan Surgi Mufti Kota berjalan baik, tertib, dan lancar. Hal ini terlihat dari antusiasme, semangat, serta kerjasama yang baik dari para ibu rumah tangga dalam mengikuti semua rangkaian kegiatan selama tiga hari hingga selesai. Para ibu rumah tangga \& remaja puteri ini diberikan pengetahuan mengenai pembuatan hand sanitizer sebagai perlengkapan protokol kesehatan di masa pandemi Covid-19 dari bahan alami yang aman.

Kegiatan pelatihan ini dilakukan dalam bentuk luring dan daring. Kegiatan ini dilaksanakan secara daring untuk memberikan pengetahuan mengenai seluk beluk pandemi Covid-19, cara adaptasi di era new normal Covid -19, serta penerapan protokol kesehatan sesuai instruksi Pemerintah dan WHO untuk mencegah paparan virus Covid-19 ini. Sementara itu, kegiatan secara daring dilaksanakan dalam rangka menghindari kerumunan masyarakat sesuai aturan protokol kesehatan tersebut. Kegiatan secara daring dilaksanakan untuk memberikan pelatihan mengenai mekanisme pembuatan hand sanitizer alami serta potensi pengembangan wirausaha dari hand sanitizer alami tersebut. Dengan diberikannya sosialisasi\& pelatihan semacam ini, diharapkan dapat 
BAKTI BANUA : Jurnal Pengabdian Kepada Masyarakat

Volume 2 No. 22021

e-ISSN : 2722-3736

p-ISSN : 2722-7529

https:/ / ejurnal.stimi-bjm.ac.id/index.php/BBJM/

memberi kontribusi dan referensi kepada masyarakat terhadap fenomena yang terjadi saat ini.

\section{Saran}

Dengan pertimbangan mendapat respon yang baik dari ibu-ibu rumah tangga di RT 27

Gg. Sei Awang Kelurahan Surgi Mufti Kota sebagai peserta kegiatan pengabdian kepada masyarakat ini, maka sudah selayaknya program- program yang bertujuan mendukung program Pemerintah dalam bidang pemberdayaan masyarakat di Indonesia sering diselenggarakan. Di masa yang akan datang, pelatihan serupa dapat diadakan kembali di daerah lain dengan tema yang sama. Selanjutnya, kegiatanseperti ini patut dijadikan sebuah program rutin tahunan atau per semester di luar jadwal akademik untuk dilaksanakan. Oleh karena itu, dibutuhkan kebersamaan para civitas akademika kampus untuk terus mendukung dan mengawal program pengabdian kepada masyarakat yang serupa.

\section{DAFTAR PUSTAKA}

Adindaputri, , Z. Purwanti, N. Wahyudi, I. A. (2013).Pengaruh Ekstrak Kulit Jeruk Nipis (Citrus aurentifolia Swingle) Konsentrasi 10\% Terhadap Aktivitas Enzim Glukosiltranferase Streptococcus mutans. Majalah Kedokteran Gigi.20 (2).126-131.

Hendarto, Y.M. 2020. Di balik Melambungnya Harga "Hand sanitizer" dan MaskerSaat Wabah Covid-19. http://kompas.id/baca/riset/2020/04/01/di-balik- melambungnya-hand-sanitizerdan-masker-saat-wabah-covid-19/. Diakses 1 Desember 2020.

Ruanti, Lia. 2018. Daya Hambat Antibakteri Perasan Jeruk Nipis (Citrus aurantifolia S) Terhadap Pertumbuhan Methicillin Resistant Staphylococcusaureus (MRSA). Manuscript. Semarang: Fakultas Ilmu Keperawatan dan Kesehatan, Universitas Negeri Semarang.

Sari, R., \& Isadiartuti, Dewi. 2006. Studi Efektivitas Sediaan Gel Antiseptik Tangan Ekstrak Daun Sirih (Piper betle Linn). Majalah Farmasi Indonesia,17(4), 163- 169, 2006.

Veronica, D.P. 2020. Benarkah Hand sanitizer Bisa Dibuat Sendiri dan Bagaimana Keamanannya?. https://alodokter.com/benarkah-hand- sanitizer-bisa-dibuat-sendiri- danbagaimana-keamanannya. Diakses 1 Desember 2020.

Wahono \& Subandi, Yeyen. 2020. Pandemi Covid-19 dan Isu Kesehatan Global. https://s3pi.umy.ac.id/pandemi-covid-19-dan-isu-kesehatan- global/. Diakses 14 Mei 2020. 


\section{Dokumentasi Kegiatan}

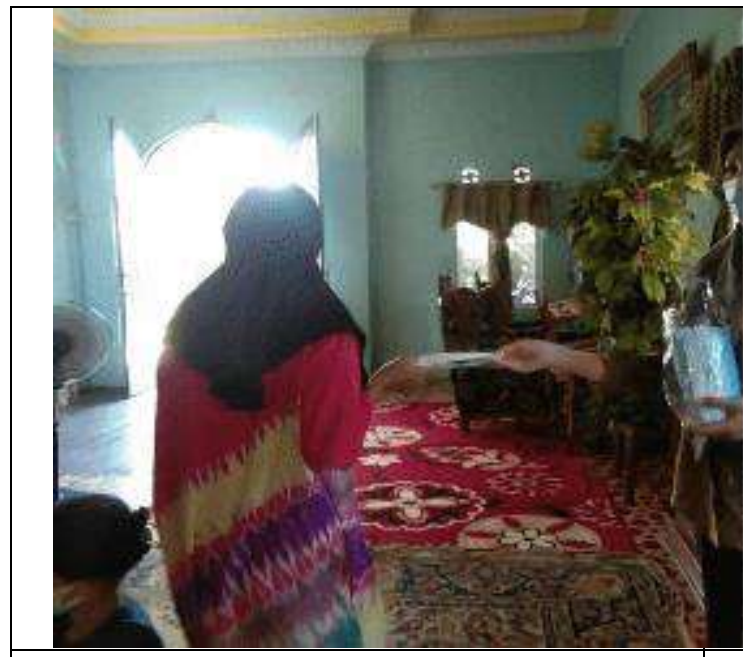

Gambar L7.1. Pembagian Masker

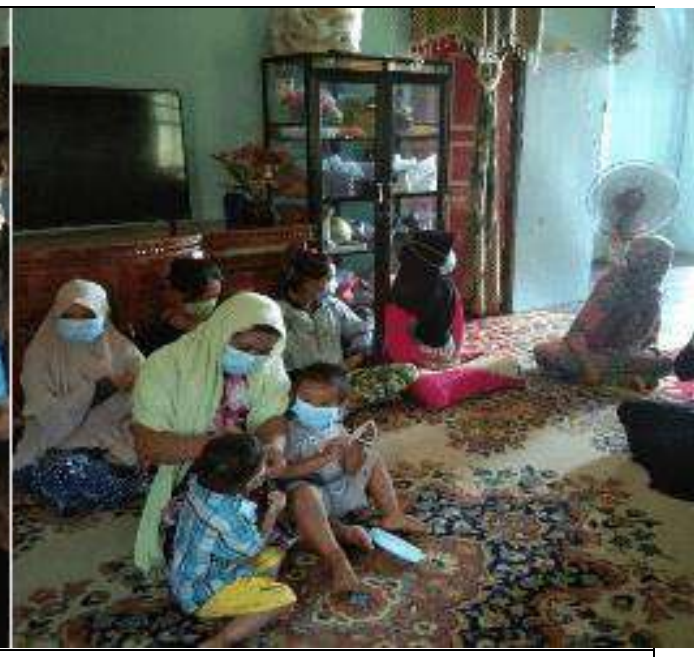

Gambar L7.2. Peserta Kegiatan Memasang Masker yang Diberikan

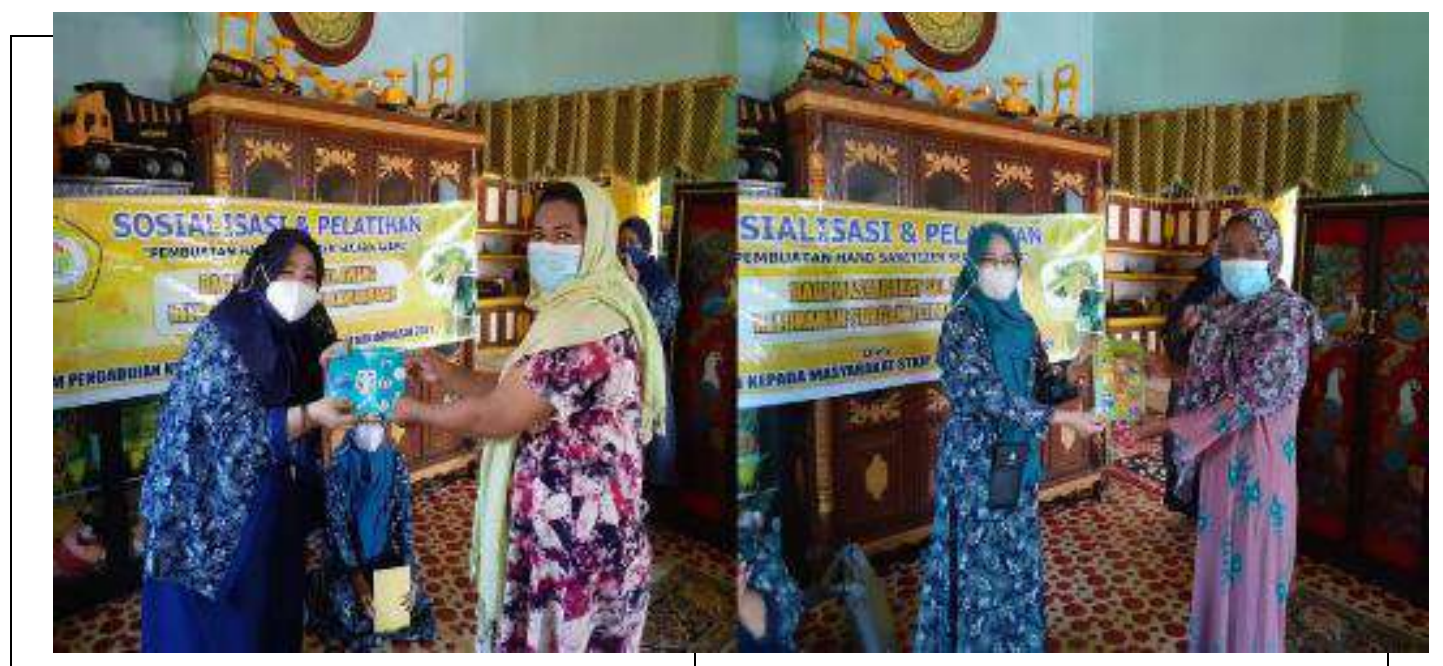

\begin{tabular}{|l|l|}
\hline Gambar L7.3. Penyerahan Brosur 1 & Gambar L7.4. Penyerahan Brosur 2 \\
\hline
\end{tabular}

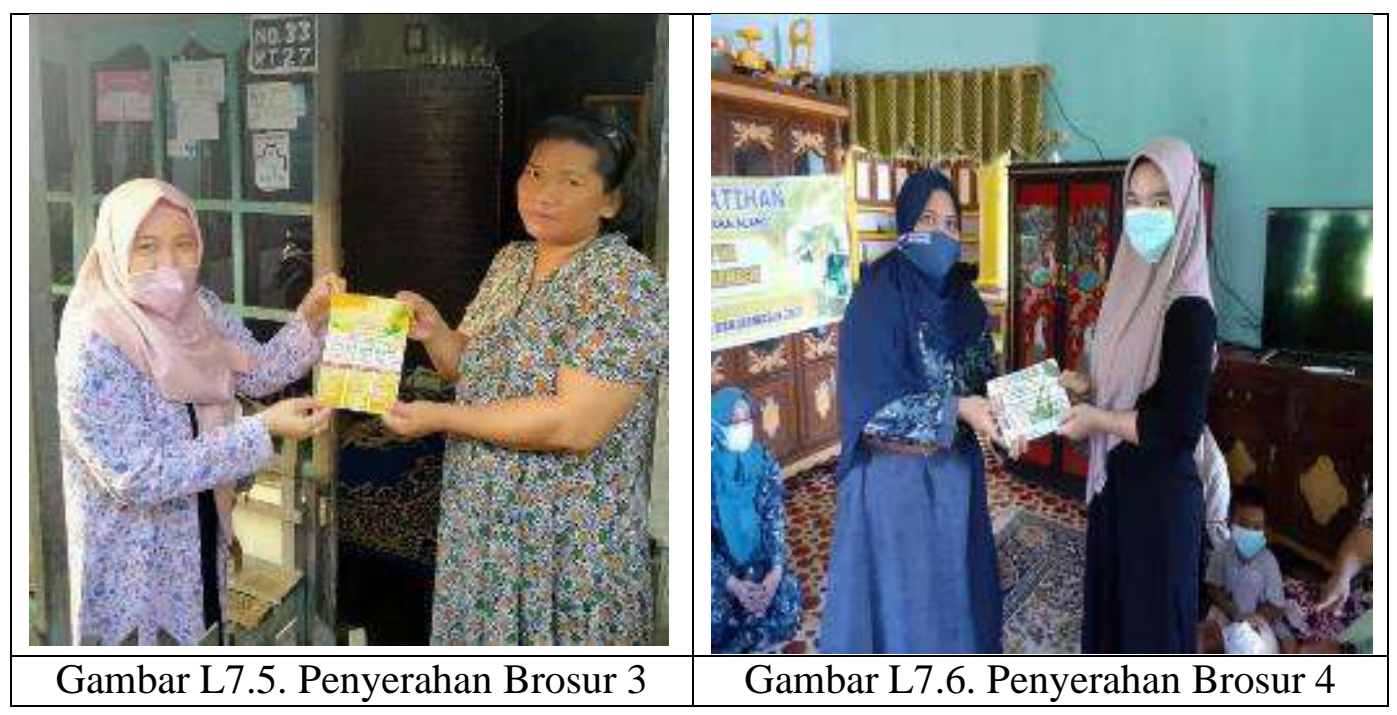

Page $\mid 60$ 


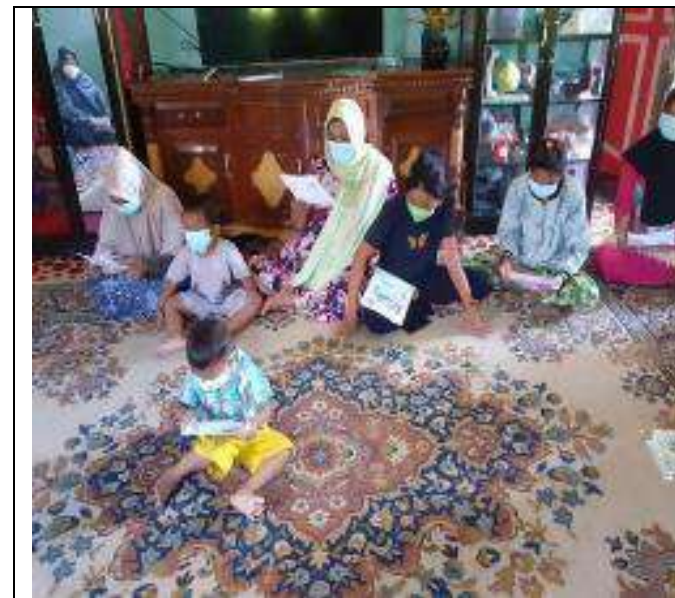

Gambar L7.7. Peserta Kegiatan Membaca Brosur yang Diberikan

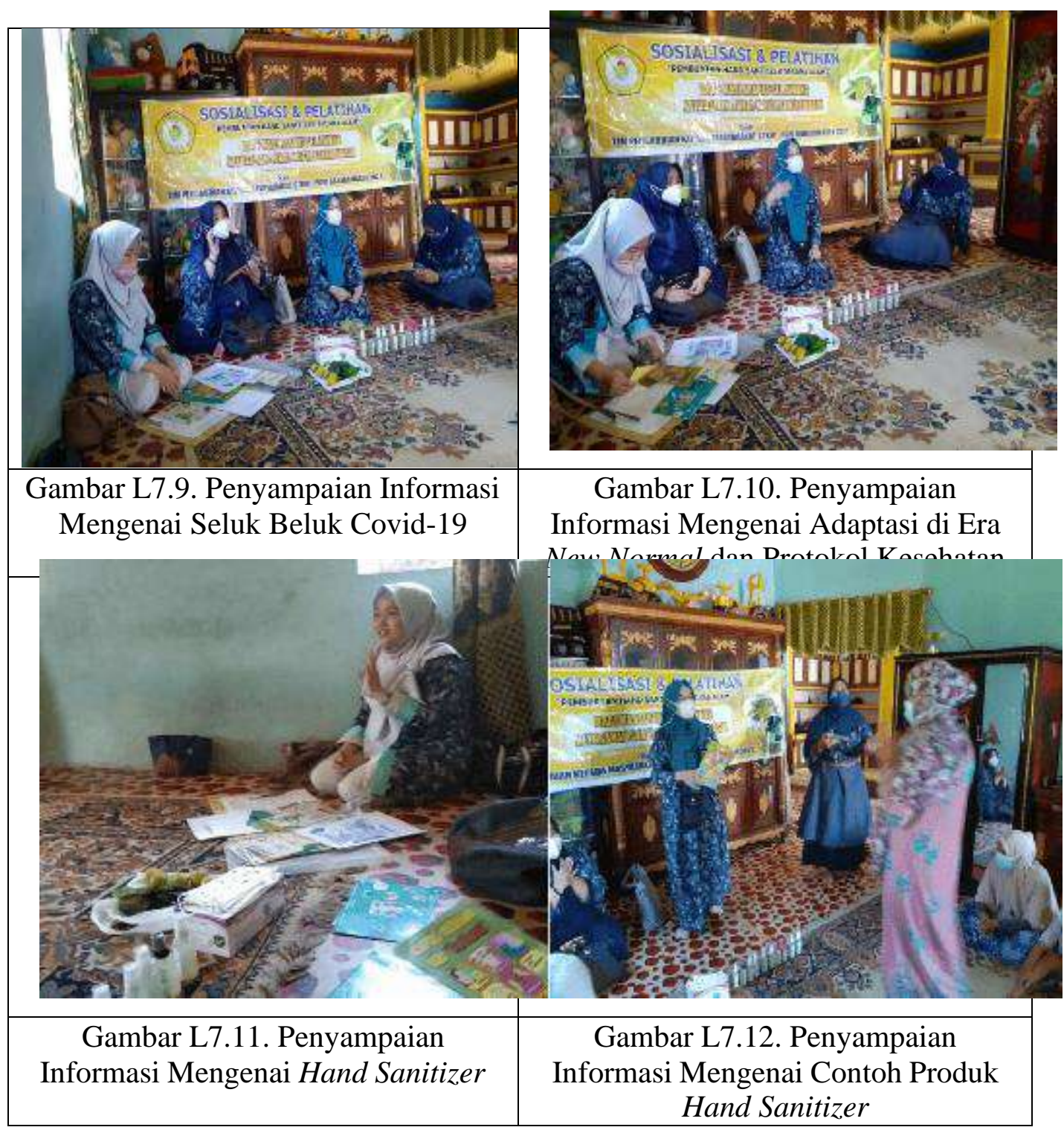



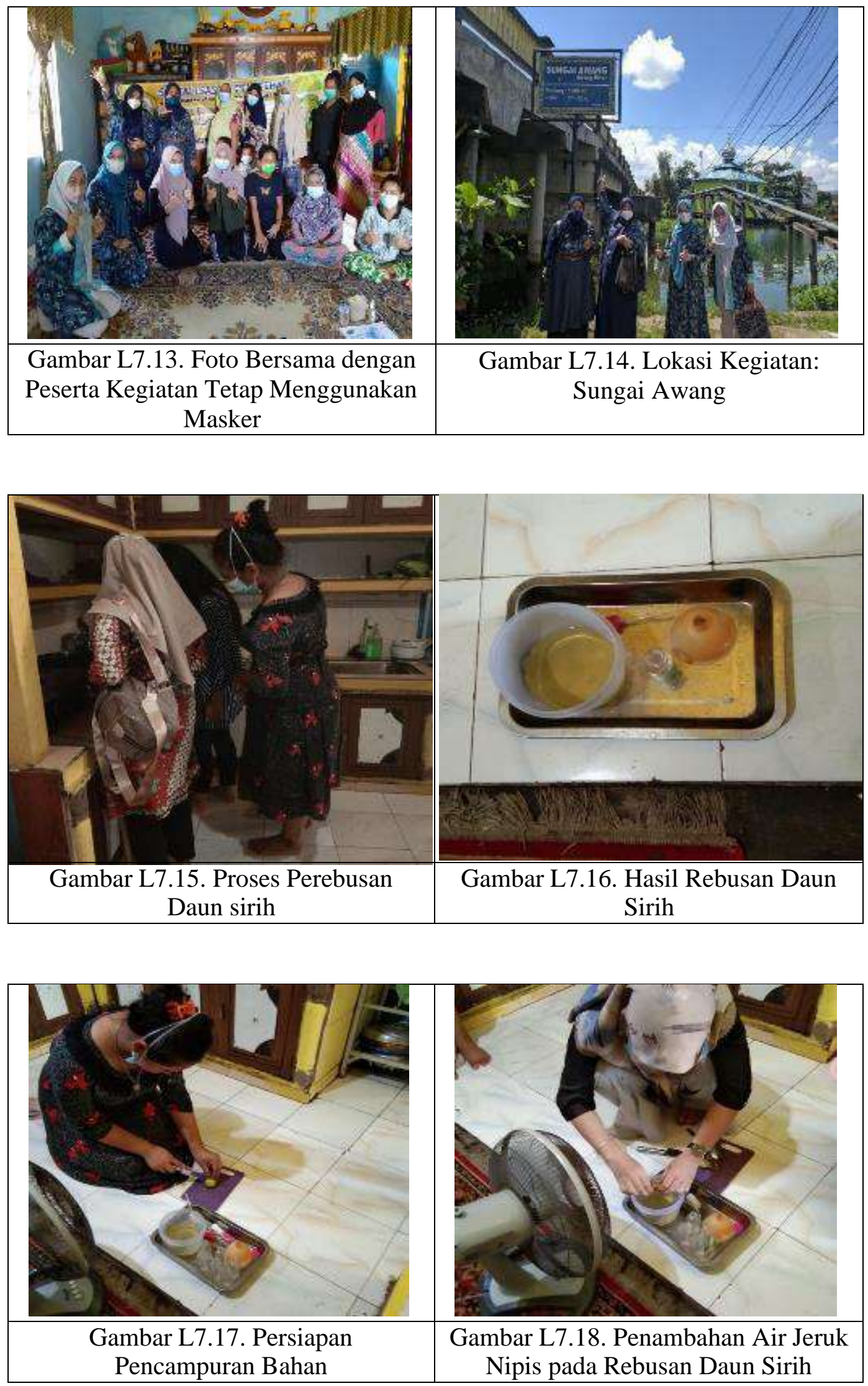


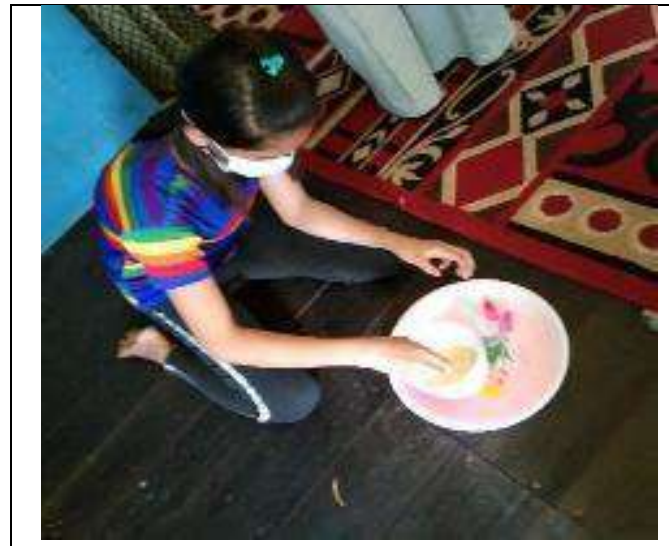

Gambar L7.19. Proses Pengadukan untuk Mencampur Air Jeruk Nipis pada Rebusan Daun Sirih

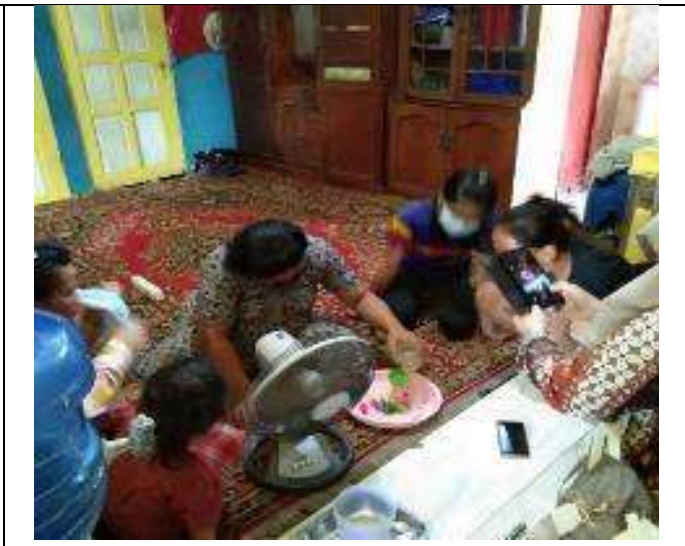

Gambar L7.20. Memasukkan Hand Sanitizer ke dalam Botol Spray
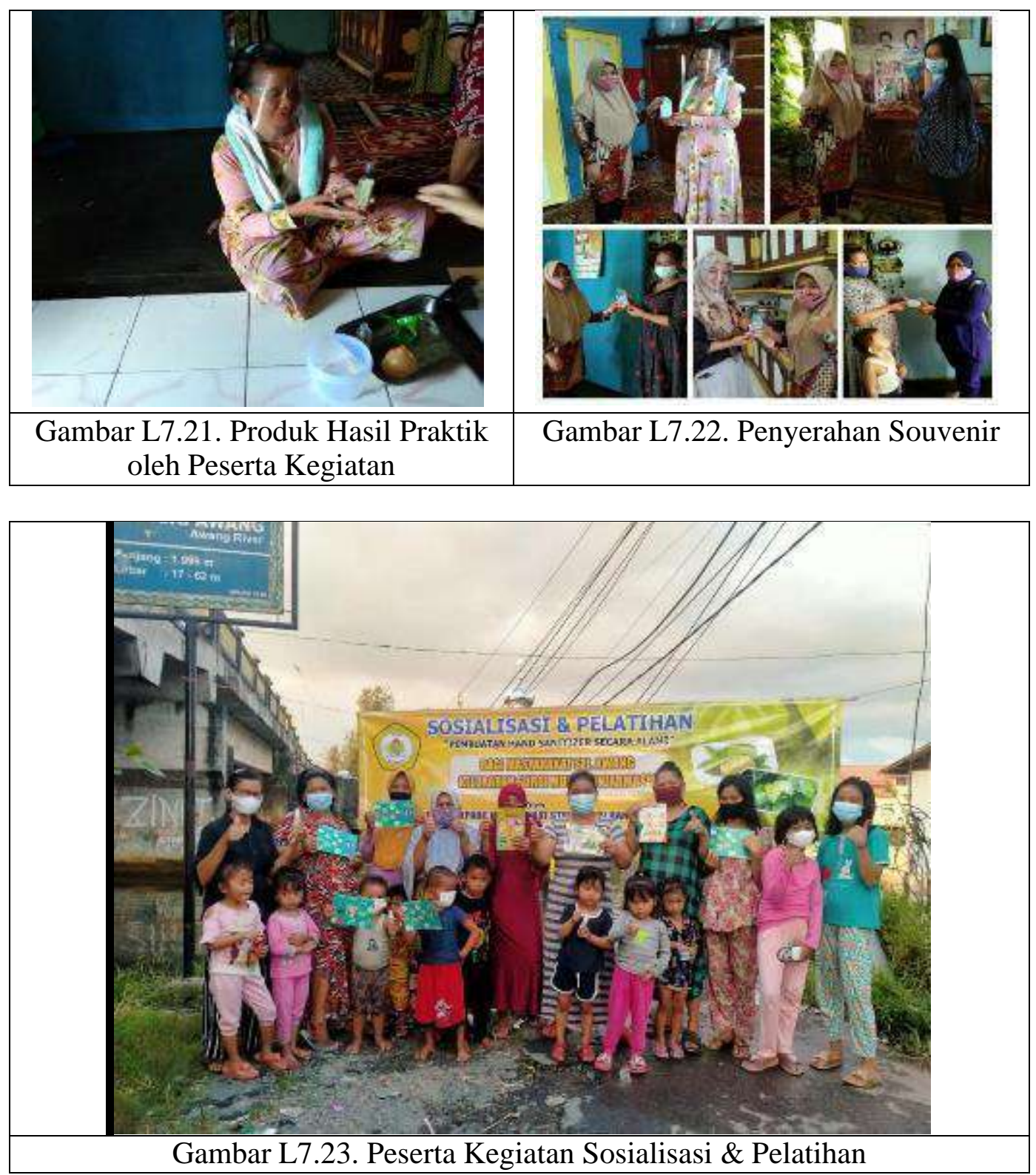